Submitted to Combustion Science and Technology

\title{
Analysis of Controlled Auto-Ignition /HCCI Combustion in a Direct Injection Gasoline Engine with Single and Split Fuel Injections
}

\author{
Li Cao, Hua Zhao*, Xi Jiang
}

School of Engineering \& Design, Brunel University, Uxbridge UB8 3PH, UK

*Corresponding Author:

Hua Zhao

School of Engineering \& Design

Brunel University, Uxbridge UB8 3PH, UK

Tel: (+44) 1895266816

Fax: (+44) 1895256392

Email: hua.zhao@brunel.ac.uk 


\begin{abstract}
:
A multi-cycle three-dimensional CFD engine simulation programme has been developed and applied to analyze the Controlled autoignition (CAI) combustion, also known as homogeneous charge compression ignition (HCCI), in a direct injection gasoline engine. CAI operation was achieved through the negative valve overlap method by means of a set of low lift camshafts. In the first part of the paper, the effect of single injection timing on combustion phasing and underlying physical and chemical processes involved was examined through a series of analytical studies using the multi-cycle 3D engine simulation programme. The analyses showed that early injection into the trapped burned gases of a lean-burn mixture during the negative valve overlap period had a large effect on combustion phasing, due to localized heat release and the production of chemically reactive species. As the injection was retarded to the intake stroke, the charge cooling effect tended to slow down the autoignition process. However, further retard of fuel injection to the compression stroke caused the earlier start of main combustion as fuel stratification was produced in the cylinder. In order to optimize the engine performance and engine-out emissions, double injection was investigated by injecting part of the fuel first in the negative valve overlap period and the rest of fuel during the intake or compression strokes. By varying the fueling of each injection, the best engine performance was obtained with the 50/50 fuel injection split ratio, while the lowest total NOx and soot emissions were seen with the optimal split injection ratio of 10/90.
\end{abstract}

Keywords: CAI, HCCI, multicycle 3D engine simulation, direct injection gasoline engine 


\section{NOTATION}

$A, p_{1} q \quad$ reaction rate constants in the main propagation reaction

ATDC

B

BDC

CAD

CAI

$\mathrm{C}_{n} \mathrm{H}_{2 m}$

CI

EVC

$f_{1}, f_{2}, f_{3}, f_{4}$

$h_{f, i}$

HCCI

HRR

IMEP

IVC

IVO

$K_{q}, K_{p}, K_{b}, K_{t} \quad$ kinetic parameters in the Shell model after top dead center

branching agent

bottom dead center

crank angle degree

controlled auto-ignition

hydrocarbon fuel

compression ignition

exhaust valve closing

constant parameters in the Shell model

heat formation of species i $(\mathrm{J} / \mathrm{kg})$

homogeneous charge compression ignition

heat release rate

indicated mean effective pressure

intake valve closing

intake valve opening 
$\mathbf{P}$

PMEP

$q_{\text {fuel }}$

Q

$Q_{\text {chem }}$

$\mathrm{R}$

SI

TDC

$Y_{m}$

\section{Greek symbols}

$\gamma$

$\phi$

\section{Subscripts}

comb

overlap oxidized products $\left(\mathrm{CO}, \mathrm{CO}_{2}, \mathrm{H}_{2} \mathrm{O}\right)$

pumping mean effective pressure

exothermicity per cycle (J/cycle)

labile intermediate species

chemical heat release rate $(\mathrm{J} / \mathrm{s})$

radical formed from fuel

spark ignition

top dead center

mass fraction of species $m$

a constant in shell model to determine the ratio of $\mathrm{CO}$ to $\mathrm{CO}_{2}$

equivalence ratio

combustion cylce

valve overlap period 


\section{INTRODUCTION}

Improving fuel economy and reducing emissions are two major challenges faced by the automotive industry. Over the recent years, a new engine combustion concept, Controlled Auto Ignition (CAI) combustion, also known as Homogeneous Charge Compression Ignition (HCCI), is receiving increased attention due to its potential for simultaneously reducing fuel consumption and NOx emissions in a gasoline engine, and its capability to remove soot and NOx emissions from a diesel engine. CAI/HCCI combustion is achieved by controlling the temperature, pressure, and composition of the fuel and air mixture, so that it spontaneously ignites in an engine. This unique characteristic of CAI/HCCI allows the combustion of very lean or diluted mixtures, resulting in low temperatures that dramatically reduce the engine-out NOx emissions. Similar to an SI engine, the combustible charge is well mixed and hence it minimizes particulate emissions. As it can be operated at wide open throttle, there is no pumping losses associated with throttling at part load and hence fuel economy of gasoline engines can be improved significantly.

It has been demonstrated that gasoline CAI combustion can be promoted by using either an increased compression ratio (Ryan III et al., 1996; Christensen et al., 1999) or heating of the intake charge (Aoyama et al. 1996, Oakley et al. 2001, Yang. et al 2002, Zhao. et al 2005). Although those approaches have been used in many fundamental studies into CAI combustion, its practical applications are limited by transient response as required in vehicular applications. Nevertheless, Haraldsson et al, 2004 has demonstrated that fairly fast response can be achieved in an HCCI gasoline engine by means of closed loop control and fast thermal management of cold ambient air and exhaust heated hot air. From the practical viewpoint, the use of recirculated or retained exhaust gases seems to be one of the most effective ways of initiating CAI combustion, since it can lead to CAI combustion at conventional geometric compression ratio and ambient temperature. In a 4-stroke gasoline engine with flexible valve actuation, residual gas trapping by early exhaust valve closure, also known as negative valve overlap, (Lavy et al., 2000; Li et al., 2001; Law et al., 2001) and exhaust gases rebreathing during the intake stroke by late exhaust valve closure or re-opening of exhaust valves (Kahaaina et al., 2001; Wolter et al., 2003) are amongst the two most successful approaches to achieve CAI/HCCI combustion in such engines.

One of the main challenges facing CAI combustion is the control of combustion phasing and the rate of heat release. One possible way of controlling the combustion phasing and to some extent the rate of the heat release is by means of direct fuel injection technology (Willand et al., 1998; Marriot and Reitz, 2002), since this provides the potential to control combustion by altering the local fuel 
distribution via varying the injection timing. In addition to this, Urushihara et al. (2003) have suggested that fuel reforming could occur with fuel injection during the negative valve overlap period in the presence of oxygen. The results from other studies (Koopmans et al., 2003; Standing et al., 2005) have also shown that the fuel oxidation reactions could proceed to the stage of combustion reactions accompanied by a small amount of heat release, if the mixture temperature during the negative valve overlap period is sufficiently high.

The benefits of using direct fuel injection in conjunction with negative valve overlap for CAI combustion phasing control were experimentally demonstrated (Urushihara et al., 2003; Koopmans et al., 2003; Standing et al., 2005). However, due to the inherent complexity of chemical kinetic mechanisms involved in the CAI combustion process and the lack of tools to provide the detailed understanding of in-cylinder transient thermal and chemical phenomena, the impacts of mixture quality, thermal and chemical effects associated with fuel evaporation and reforming, on CAI combustion are still not well understood. Consequently, the objective of this study is to systematically investigate the thermal and chemical effects of variable fuel injection timings and split injection ratios on mixture stratification, CAI combustion and its emissions, by using a multi-cycle 3D simulation approach.

\section{MODELING DESCRIPTION}

The multi-cycle 3D CFD engine simulation programme is based on the KIVA3V code (Amsden, 1999), with improvements in turbulence, gas/wall heat transfer, spray breakup, ignition and combustion models. The RNG- $\kappa--\varepsilon$ turbulence model is used for the engine flow simulation; the current wall heat transfer model (Han and Reitz 1997a) uses a modified temperature wall function to account for density variations in the boundary layers; a liquid sheet breakup spray model is applied to simulate pressure swirl spray atomization. Details of the theoretical development and validation of the model can be found in reference (Han et al., 1997b). Moreover, due to the fact that detailed chemical kinetics model coupled with multi-dimensional simulation is far beyond the current computing capacity, a realistic reduced kinetics model based on the multi-step Shell ignition model has been chosen to simulate the autoignition process.

\section{Reduced chemical kinetic ignition model}

Although the Shell model was originally developed to predict the onset of knocking combustion in a gasoline engine, it has been successfully extended to simulate the auto-ignition processes of a 
number of hydrocarbon fuels in the compression-ignited engines. In the Shell model (Halstead et al., 1977), the auto-ignition chemistry is reduced to an eight-step chain branching reaction mechanism incorporated into such four processes as follows:

Initiation:

$$
\mathrm{C}_{n} \mathrm{H}_{2 m}+\mathrm{O}_{2} \rightarrow 2 \mathrm{R} \quad K_{q}
$$

Propagation:

$$
\begin{array}{lr}
\mathrm{R} \rightarrow \mathrm{R}+\mathrm{P}+\text { Heat } & K_{p} \\
\mathrm{R} \rightarrow \mathrm{R}+\mathrm{B} & f_{1} K_{p} \\
\mathrm{R} \rightarrow \mathrm{R}+\mathrm{Q} & f_{4} K_{p} \\
\mathrm{R}+\mathrm{Q} \rightarrow \mathrm{R}+\mathrm{B} & f_{2} K_{p}
\end{array}
$$

Branching:

$$
\mathrm{B} \rightarrow 2 \mathrm{R}
$$

Termination:

$$
\begin{aligned}
& \left.\mathrm{R} \rightarrow \text { nonreactive species(eg. } \mathrm{N}_{2}\right) \quad f_{3} K_{p} \\
& \text { 2R } \left.\rightarrow \text { nonreactive species (eg. } \mathrm{N}_{2}\right) \quad K_{t}
\end{aligned}
$$

where $\mathrm{C}_{n} \mathrm{H}_{2 m}$ is the hydrocarbon fuel, $\mathrm{R}$ is radical formed from fuel, $\mathrm{B}$ is branching agent, $\mathrm{Q}$ is labile intermediate species and $\mathrm{P}$ is oxidized products, consisting of $\mathrm{CO}, \mathrm{CO}_{2}$ and $\mathrm{H}_{2} \mathrm{O}$ in specified proportions. $K_{q}, K_{p}, K_{b}, K_{t}, f_{1}, f_{2}, f_{3}$ and $f_{4}$ are the kinetic parameters given in Halstead et al. 1977. 
In order to improve the generality and robustness of the Shell model, the original Shell model has been modified to take the mass contributions of the intermediate species into account. As it has been shown previously (Kong et al. 1995), the propagation reactions (Eqs. (2) - (5)) can be combined into a main propagation cycle subject to mass conservation as:

$$
\mathrm{C}_{n} \mathrm{H}_{2 m}+p_{1} \mathrm{O}_{2} \rightarrow \frac{1}{A+1} \cdot\left(q \mathrm{P}+f_{1} \mathrm{~B}+f_{4} \mathrm{Q}\right)
$$

Where $A=\frac{f_{1} W_{\mathrm{B}}+f_{4} W_{\mathrm{Q}}}{\frac{1}{m} W_{\mathrm{C}_{\mathrm{n}} \mathrm{H}_{2 \mathrm{~m}}}+p_{1} W_{\mathrm{O}_{2}}}, \quad p_{1}=\frac{n(2-\gamma)+m}{2}$ and $q=n+m, W$ is the molecular weight of species, the coefficient $\delta$ is a constant of 0.67 , which determines the fixed ratio of burnt products of $\mathrm{CO}$ to $\mathrm{CO}_{2}$ via $\frac{\gamma}{1-\gamma}$, based on a general survey of analytical studies of hydrocarbon oxidation systems (Halstead et al. 1977). It is assumed that the main propagation cycle is the only step in which the heat is released. As a result, the heat release rate is calculated from the main propagation step (Eq. 9) by $q_{\text {fuel }} \times$ fuel consumption rate, where $q_{\text {fuel }}$ is the exothermicity per cycle. The empirical parameter $q_{\text {fuel }}$ is dependant on the type of fuel used. In the current study, two changes have been made to the calculations related to the autoigntion process. The first modification is to calculate the heat release rate using the energy balance of the above propagation cycle.

$$
Q_{\text {chem }}=\sum_{\text {products }} \dot{m}_{i} h_{f, i}-\sum_{\text {reactants }} \dot{m}_{j} h_{f, j}
$$

where $Q_{c h e m}$ is the chemical heat release rate, $\dot{m}_{i}$ is the conversion rate of species $i, h_{f, i}$ is the heat formation of species $i$.

The second modification is related to the inert products of the two termination reactions. In the original scheme (Halstead et al. 1977), the radical $\mathrm{R}$ is assumed to be removed by converting into an inert species such as $\mathrm{N}_{2}$. Based on the fact that auto-ignition and post-ignition combustion are closely related processes, it can be assumed that the products in the two termination reactions (Eq.7 and Eq.8) should be the same species as the final products in high temperature combustion (consisting of CO, $\mathrm{CO}_{2}$ and $\mathrm{H}_{2} \mathrm{O}$ ).

In the Shell autoignition model, the elementary reaction steps are empirical, and only represent the gross behavior of detailed chemistry models. Thus, certain parameter fitting is necessary before the 
autoignition model is extended to application of different fuels and operating conditions. By tuning against the available experimental data ( $\mathrm{Li}$ et al. 2001), the pre-exponential constants $A_{f 1}$ and $A_{f 4}$ of the reaction rate in the reactions of Eqs. 3 and 4 were modified to $8.5 \times 10^{-3}$ and $5.0 \times 10^{3}$, respectively, while the other kinetics parameters used the values of RON 90 fuel. A comparison of heat release traces of the experimental and computational results is given in Fig.1. As can be seen, both the standard and the modified Shell models slightly under-predict the low temperature heat release, due to the difficulties in reproducing the complete chemical behavior in the low-temperature reactions by the reduced autoignition mechanisms. Nevertheless, as shown in Fig.1, the prediction of heat release prior to the main combustion with the modified Shell model has been improved over the original model. More detailed model validations under different operating conditions were given in earlier publication (Cao et al., 2005).

\section{Characteristic-time combustion model}

Since the Shell model does not include any reaction for high-temperature heat release, the overall combustion is modeled by a characteristic-time combustion model (Kuo and Reitz, 1992) combined with the Shell autoignition model. The transition from the auto-ignition to the main combustion process is based on the local cell temperature: when the temperature of a cell exceeds $1080 \mathrm{~K}$, which was obtained from the previous experimental validation (Cao et al., 2005), high temperature combustion model is activated for such a cell. With the characteristic-time combustion model, the rate of change in the mass fraction of species $m$ is written as:

$$
\frac{d Y_{m}}{d t}=-\frac{Y_{m}-Y_{m}^{*}}{\tau_{c}}
$$

where $Y_{m}$ is the mass fraction of species $m, Y_{m}^{*}$ is the local and instantaneous thermodynamic equilibrium value of mass fraction, and $\tau_{c}$ is the characteristic time to reach such equilibrium. The present computation considers 7 species: fuel, $\mathrm{O}_{2}, \mathrm{~N}_{2}, \mathrm{H}_{2} \mathrm{O}, \mathrm{CO}_{2}$, $\mathrm{CO}$, and $\mathrm{H}_{2}$.

\section{NOx and soot production models}


The extended Zel'dovich mechanism is used to predict NOx concentration, as given by the following reactions (Borman, 1975):

$$
\begin{aligned}
& O+N_{2} \leftrightarrow N O+N \\
& N+O_{2} \leftrightarrow N O+O \\
& N+O H \leftrightarrow N O+H
\end{aligned}
$$

These reactions are solved by assuming a steady-state population of $N$ and equilibrium for $\mathrm{O}+\mathrm{OH} \leftrightarrow \mathrm{O}_{2}+\mathrm{H}$. The formation of $\mathrm{NO}_{x}$ from this model is governed by

$$
\frac{d\left[N O_{x}\right]}{d t}=\frac{2 R_{1}\left\{1-\left([N O] /[N O]_{e}\right)^{2}\right\}}{1+\left([N O] /[N O]_{e}\right) \cdot R_{1} /\left(R_{2}+R_{3}\right)} \cdot \beta_{N O}
$$

where [ ] means equilibrium state and [ ] is assumed to be at steady state. $R_{1}, R_{2}$ and $R_{3}$ are the rate coefficients given in Heywood (1988). $\beta_{N O}$ is a constant, which allows the model to be adjusted from converting $\mathrm{NO}$ to $\mathrm{NOx}$, comparable to the EPA $\mathrm{NO}_{2}$-based standard.

The current model for soot production is based on a model proposed by Hiroyasu and Nishida (Hiroyasu et al., 1989), in which the production of soot mass is calculated by the rate of change in soot concentration from the formation and oxidation rates

$$
\frac{d M_{s}}{d t}=\dot{M}_{s f}-\dot{M}_{\text {so }}
$$

where the formation rate $\dot{M}_{\text {sf }}$ is given by

$$
\dot{M}_{s f}=A_{s f} P^{0.5} \exp \left(-E_{s f} / R T\right) \cdot M_{f v}
$$

where $M_{f v}$ is the fuel vapor mass, $E_{s f}$ is the activation energy and $A_{s f}$ is the Arrhenius pre-exponential factor set equal to 500 in the present study.

To model soot oxidation rate $\dot{M}_{\text {so }}$, the Nagle and Strickland-Constable model (Nagle et al., 1962 ) is used, which considers carbon oxidation by two mechanisms whose rates depend on surface 
chemistry involving the more reactive A sites and the less reactive B sites. The net reaction rate is given by

$$
R_{\text {total }}=\left(\frac{K_{A} P_{O 2}}{1+K_{Z} P_{O 2}}\right) \cdot X+K_{B} P_{O 2} \cdot(1-X)
$$

where $X$ is the proportion of A sites given by

$$
X=\frac{P_{O 2}}{P_{O 2}+\left(K_{T} / K_{B}\right)}
$$

In the above equations, $P_{O 2}$ is the oxygen partial pressure and $K_{A}, K_{B}, K_{T}$ and $K_{Z}$ are the rate constants given by Rutland et al., (1994).

Finally, the soot mass oxidation rate $\dot{M}_{\text {so }}$ is given by

$$
\dot{M}_{\text {so }}=\frac{6 M_{w c}}{\rho_{s} d_{s}} \cdot M_{s} R_{\text {total }}
$$

where $M_{w c}$ is the molecular weight of carbon, $\rho_{s}$ is the soot density, $d_{s}$ is the soot diameter and $M_{s}$ is the soot mass.

\section{MULTI-CYCLE 3D ENGINE SIMULATION AND FUEL INJECTION STRATEGE}

Most multi-dimensional CFD simulation studies of CAI combustion engines were carried out for the period of closed valves. Although the partial engine cycle simulation (Aceves et al. 2000) is useful when investigating fundamental issues, such as the effect of alternative chemistry schemes, or heat transfer treatments on ignition prediction, it does not capture the initial mixture state (i.e. the trapped internal residual gas and mixture compositions). This characteristic would be greatly disadvantageous in the context of investigation into the negative valve overlap method, in which the treatment of the gas exchange process is critical to the capturing of large amounts of trapped residual gases and thermal effect of fuel evaporation during valve opening period in the present study. The main advantage of the CAI full cycle simulation over the partial engine cycle simulation is that it directly computes gas exchange process, as well as the internal residuals trapped in the engine cylinder. Furthermore, it 
converges to a steady state solution through a series of iterations in a manner of the multi-cycle simulation, and hence the uncertainties of initial condition in simulation can be progressively resolved by this approach.

The method selected in the present CAI combustion study is the retention of large amounts of residual gases, in order to recuperate sufficient thermal energy from the exhaust gas to allow the fuel to auto-ignite and to dilute the charge mixtures to the level necessary to control the subsequent heat release rate. This method, referred to as the negative valve overlap approach, is achieved by closing the exhaust valves early and retarding the intake valves openings simultaneously, as illustrated in Fig. 2. As shown in Fig.2, both the intake and exhaust valve opening durations have been reduced substantially, and their maximum valve lifts are modified to be about $20 \%$ of those of the standard camshafts.

In the present study, multi-cycle simulation started in the SI combustion mode in the first cycle at IVC, so as to generate and trap sufficient residual gas to initiate CAI combustion for the next cycle. The simulation convergence was reached, only if the difference of in-cylinder temperature at $\mathrm{TDC}_{\text {overlap }}$ between the two consecutive cycles was within 1\%. It usually took 5 or 6 full engine cycles of CAI combustion to reach a steady state cycle independent of the initial condition. All the model constants needed in the Shell autoignition and high-temperature combustion models have been tuned and validated against the relevant experimental data as detailed elsewhere (Cao et al., 2005).

The burned gases trapped would contain excessive oxygen, if a lean mixture is burned from the previous cycle. It is considered that fuel injection into such residual gases during the negative valve overlap period could be used to assist the CAI combustion process. Figure 3 shows the fuel injection strategies used, in which the in-cylinder pressure trace indicated by solid line is also included. As shown in Fig. 3, the following three injection strategies are used to systematically investigate the effect of single fuel injection timing:

1) Injection during the negative valve overlap period, in which fuel is injected into the hot oxygen containing residual gases in the cylinder for the purpose of reforming the fuel or initiating the minor combustion, if possible, to increase charge temperature for improving ignitability. (As such, fuel is injected at $-75^{\circ},-40^{\circ},-20^{\circ}$ ATDC $C_{\text {overlap }}$ and at $\mathrm{TDC}_{\text {overlap }}$ respectively) 
2) Injection during the intake stroke to create a homogeneous mixture and increase volumetric efficiency by charge cooling effect. (As shown in Fig. 3, two injection timings of SOI at $98^{\circ}$ and $150^{\circ} \mathrm{ATDC}_{\text {overlap }}$ are selected)

3) Injection during the compression stroke (SOI at $218^{\circ} \mathrm{ATDC}_{\text {overlap}}$ ) with the aim of forming a stratified-charge mixture and controlling ignition timing.

The specifications of the modeled engine shown in Fig. 4 are listed in Table 1. The fuel injector is located on the intake side of the combustion chamber and its spray parameters are also included in Table 1. In all the injection cases studied, the same amount of fuel $\left(9 \mathrm{mg}\right.$ and $30^{\circ} \mathrm{CA}$ injection duration) is injected in each engine cycle so as to maintain a constant fueling. It should be noted that the overall equivalence ratio for all the examined cases varies slightly around 0.8 . This is due to the fact that the charge cooling effect occurring during the intake process would lead to extra air being trapped in the cylinder, and hence slightly lower equivalence ratio. The same initial and boundary conditions are used for all the computations. An intake air temperature of $320 \mathrm{~K}$ and the constant pressure boundary condition of $0.1013 \mathrm{MPa}$ are used. The engine speed is fixed at $1500 \mathrm{rpm}$. Since the primary objective of this study is not to address the effect of valve timing on the CAI combustion process, the EVC and IVO timings are fixed at $-85^{\circ}$ and $88^{\circ} \mathrm{ATDC}_{\text {overlap }}$ to obtain stable CAI combustion. In addition to the single injection studies, double injection has been studied, in which the starts of the first and second injections are fixed at $-75^{\circ}$ and $98^{\circ} \mathrm{ATDC}_{\text {overlap }}$, while the split injection ratio is varied between the two injections.

\section{RESULTS AND DISCUSSION}

\section{Evaluation of Autoignition and Combustion Models for CAI Combustion in a DI}

\section{Gasoline Engine}

In the Shell auto-ignition model, the low temperature reactions start from the initiation reaction where the fuel molecule and oxygen produce a radical R (Eq. 1). The main propagation reaction (Eq. 2) follows and releases heat. In the mean time, the radical R could also propagate and produce the branching agent B (Eq. 3). This reaction is responsible for the first-stage ignition. However, the dominance of this reaction decreases after a slight temperature rise and cool flame phenomena are observed. Therefore, a first-order termination reaction is set up for taking radicals out of propagation cycle (Eq. 7). This reaction dominates in the moderate temperature range and slows down the overall 
reaction during the second induction period. During or after the appearance of cool flame, intermediate species Q is formed (Eq. 4), and then the branching agent is reproduced via the intermediate species (Eq. 5). Subsequently the branching reaction builds up the radical pool leading to hot ignition (Eq. 6). Finally, a quadratic termination serves as the terminator of radicals (Eq.8). As can be seen, the intermediate species Q and branching agent B are of special importance to this model. Based on the sensitivity studies undertaken by Kong et al., (1995), the formation of Q is thought to be a crucial reaction leading to hot ignition.

In order to clarify the role of fuel reforming and heat release associated with fuel injection in the negative valve overlap period, a sensitivity study of the effect of chemical and thermal contributions on the CAI combustion process was first carried out by enabling either auto-ignition model or main combustion model, or both models during the negative valve overlap period, for a fixed injection timing of $-40^{\circ} \mathrm{ATDC}_{\text {overlap }}$ with all other conditions given in Table 1.

1. Case 1: only the Shell auto-ignition model is activated within the whole temperature range during the negative valve overlap period, in order to investigate the chemical effect due to fuel reforming.

2. Case 2: only the characteristic-time combustion model is activated during the negative valve overlap period, such that the heat release or thermal effect can be evaluated.

3. Case 3: switch from the Shell auto-ignition model to the characteristic-time model at $1080 \mathrm{~K}$ during the negative valve overlap period.

It should be noted that both Shell auto-ignition and characteristic-time combustion models were used during the rest of cycle. The predicted in-cylinder temperature and heat release profiles for all three cases with injection at $-40^{\circ} \mathrm{ATDC}_{\text {overlap }}$ are shown in Fig. 5 (a). As shown in Fig. 5 (a), heat release predicted by the high temperature characteristic-time model is much greater than that predicted by the Shell auto-ignition model. As a result, the early heat release during the negative valve overlap period is almost exclusively due to high temperature combustion predicted by the characteristic-time combustion model used in Cases 2 and 3, contributing to higher mixture temperature before the appearance of the first-stage of ignition $\left(310^{\circ} \mathrm{CA} \mathrm{ATDC}_{\text {overlap}}\right)$. Case 1 is characterized with higher levels of intermediate species $\mathrm{Q}$ and radical $\mathrm{R}$ during the negative valve overlap period as shown in Fig. 6 and larger first heat release around $315^{\circ} \mathrm{CA} \mathrm{ATDC}_{\text {overlap }}$ during the first-stage of ignition in the compression stroke, contributing to a faster temperature rising and much earlier auto-ignition than that 
in Cases 2 and 3. As also shown in Fig. 5, Case 2 and Case 3 show similar heat release during the negative valve overlap period, but Case 3 has a slightly higher first-stage heat release at $315^{\circ} \mathrm{CA}$ $\mathrm{ATDC}_{\text {overlap }}$ and earlier start of main combustion. The difference in the first stage and main heat release between the two cases can be explained by the higher values of $\mathrm{R}$ and $\mathrm{Q}$ present in Case 3, due to fuel reforming effect during the negative valve overlap period. In order to assess the validity of the three cases studied, a net heat release curve from a DI gasoline engine running in CAI combustion with the negative valve method (Standing et al., 2005) is plotted in Fig. 5 (b). As it can be seen, using the Shell-auto-ignition model only (Case 1) does not predict the heat release during the negative valve overlap period, which is apparent in the experimentally derived heat release curve, and it over predicts the first stage heat release during compression and hence too early start of combustion. Case 2 (with the characteristic-time combustion model only during the negative valve overlap) fails to predict the first stage heat release around $315^{\circ} \mathrm{CA} \mathrm{ATDC}_{\text {overlap}}$, which are caused by the accumulation of radical $\mathrm{R}$ and labile intermediate species Q. However, the PLIF measurements (Koopmans et al., 2003) show that formaldehyde is formed with injection during the negative valve overlap, indicating some low temperature oxidation reactions taking place during this period. The above experimental results and the model sensitivity study demonstrate that the combined Shell and characteristic-time combustion models should be used so that the chemical and thermal contributions can be included due to fuel reforming and minor combustion during the negative valve overlap period. This combined combustion model should therefore be used for the following parametric studies.

Perhaps, more importantly, the above analysis shows that fuel injection into a lean-burn mixture during the negative valve overlap period can cause both localized heat release during this period and promote fuel oxidation reactions or fuel reforming. The localized heat release during the negative valve overlap period is shown to be dominated by the high temperature reactions but its value is limited by the amount of oxygen available. The fuel reforming has been found to be responsible for the presence of the two-stage heat release in the compression stroke seen during the experimental studies.

\section{Effects of Single Fuel Injections}

\subsection{Charge cooling effect due to direct injection}

As shown in Table 2 and Fig. 7, the charge cooling effect associated with fuel evaporation has been found to influence the engine performance by altering its volumetric efficiency, pumping loss, and compression temperature. In a direct injection gasoline engine, fuel is injected directly into the 
cylinder and then vaporized completely by absorbing heat only from the in-cylinder charge mixture. Reducing the in-cylinder temperature results in decreased cylinder pressure, which can lead to an increase of intake airflow mass during the intake stroke. As shown in Table 2, the highest airflow rate can be seen with injection taking place at $98^{\circ} \mathrm{CA} \mathrm{ATDC}_{\text {overlap }}$ near IVO, while the charge cooling induced volumetric efficiency benefit vanishes with injection after IVC. The reduced airflow rate with injection during the recompression process is due to the fact that the early heat release during the negative valve overlap period offsets the charge cooling effect to some extent.

Another significant effect of charge cooling is on pumping loss. Higher pumping losses can be seen with injections during the negative valve overlap period, as compared with that of injections during the intake and compression strokes. This may be explained by referring to Fig. 7 (b), where incylinder pressure traces are plotted for different injection timings. It can be seen from Fig. 7 that injection during the recompression process lowers the re-expansion pressure after $\mathrm{TDC}_{\text {overlap}}$, due to fuel evaporation and its associated charge cooling effect, and hence increased pumping work. In addition, it is noted that advancing injection timing tends to lower pumping losses, when fuel injection takes place in the negative valve overlap period. This is mainly due to the fact that more heat is released in the re-expansion process owing to minor combustion, which in turn increases the reexpansion work and hence reduces the pumping work associated with the recompression process.

\subsection{Early injections during the negative valve overlap period}

By injecting fuel directly into the trapped and recompressed hot residuals of lean-burn mixtures prior to the intake process, fuel could undergo varying degrees of chemical preconditioning reactions and even some heat release as discussed previously. Figure 8 shows the spatial distributions of charge temperature, equivalence ratio, local heat release rate and soot at $\mathrm{TDC}_{\text {overlap }}$ with injections during the negative valve overlap period. These results show that the heat release process always starts at the boundary of the fuel rich zone, where high temperature and oxygen availability favour the exothermic reactions, while the soot contours coincide with the fuel rich zones within the minor combustion region during the negative valve overlap period. The temperature evolution and the early heat release associated with minor combustion during the negative valve overlap period are given in Fig. 9. It is noted that the case with injection at $-40^{\circ} \mathrm{ATDC}$ overlap leads to more heat released during the negative valve overlap period than the other three injections. Approximately $3 \%$ of the total fuel energy is released during the negative valve overlap period with injection at $-40^{\circ} \mathrm{ATDC}_{\text {overlap}}$, as compared with $1.5 \%, 2.6 \%$ and $0.5 \%$ with injections at $-75^{\circ},-20^{\circ} \mathrm{ATDC}_{\text {overlap }}$ and $\mathrm{TDC}_{\text {overlap }}$ respectively. The amount of heat released during the negative valve overlap is limited by the oxygen available as well as local 
charge temperature. As shown in Fig. 9, injection at $-75^{\circ} \mathrm{ATDC}_{\text {overlap }}$ lowers the charge temperature during the negative valve overlap so much that the heat release is largely limited by charge temperature. By comparison, lower charge temperature in the re-expansion process due to charge cooling effect and downward piston motion contribute to less heat released during the negative valve overlap with injections $-20^{\circ} \mathrm{ATDC}_{\text {overlap }}$ and $\mathrm{TDC}_{\text {overlap }}$ than that with injection at $-40^{\circ} \mathrm{ATDC}_{\text {overlap }}$.

The corresponding pressure and heat release rate profiles during the negative valve overlap period and main combustion processes are given in Fig. 10. As can be seen, the highest peak pressure and earliest combustion phasing are seen with injection at $-40^{\circ} \mathrm{ATDC}_{\text {overlap}}$, which also has the largest amount of early heat release during the negative valve overlap period. This indicates that the early heat release associated with minor combustion during the negative valve overlap period is primarily responsible for the advanced start of main combustion, due to an elevated in-cylinder charge temperature during the intake and compression strokes shown in Fig. 9. As shown in Table 3, the crank angles of $10 \%$ MFB with injections at $-40^{\circ}$ and $-20^{\circ}$ ATDC ${ }_{\text {overlap }}$ are advanced by $7.4^{\circ}$ and $6.0^{\circ}$ CA respectively, as compared with the injection at $\mathrm{TDC}_{\text {overlap }}$. This suggests that the thermal effect due to the early heat release in the negative valve overlap period is dominant in those two injections cases.

For injections at $-75^{\circ} \mathrm{ATDC} \mathrm{C}_{\text {overlap }}$ and $\mathrm{TDC}_{\text {overlap }}$, the thermal effect becomes less significant due to a relatively small heat released during the negative valve overlap period. However, larger amount of heat is released during the first stage of ignition at $320^{\circ} \mathrm{ATDC}_{\text {overlap }}$, although a slightly lower charge temperature during the intake and early part of compression strokes is observed, as shown in Figures 8 and 9. This can be explained by referring to Fig. 11, which shows the trace of labile intermediate species Q. As can be seen, large amounts of intermediate species Q formed during the negative valve overlap period with injection at $-75^{\circ} \mathrm{ATDC}_{\text {overlap }}$ can promote quick build-up of branching agent $\mathrm{B}$, which leads to higher heat release at the first-stage of ignition as seen in Fig. 9.

The main combustion characteristics for injections during the negative valve overlap period are summarized in Table 3. The value of net IMEP is closely related to combustion phasing and pumping loss. Both too early combustion phasing and higher pumping losses contribute to lower IMEP values with injections at $-40^{\circ}$ and $-20^{\circ} \mathrm{ATDC}_{\text {overlap }}$, as compared with the injection at $-75^{\circ} \mathrm{ATDC}_{\text {overlap }}$. Comparing the cases with injections at $-75^{\circ} \mathrm{ATDC}$ overlap and $\mathrm{TDC}_{\text {overlap }}$, the combustion phasings of those two injection cases are quite similar, however the higher pumping losses result in lower IMEP with injection at $\mathrm{TDC}_{\text {overlap }}$.

\subsection{Mid and late injections during the intake and compression strokes}


Figure 12 shows the pressure and heat release rate varying with injection timings. Comparing the two injections during the intake stroke, the start of combustion is slightly retarded with later injection timing (SOI at $150^{\circ} \mathrm{ATDC}_{\text {overlap }}$ ), leading to lower peak pressure. As shown in Table 4, there is little difference in the compression temperature between the two injections during the intake stroke. The delayed start of combustion with later injection is therefore likely related to the time available for fuel to mix with air and to be oxidized. However, the combustion phasing is advanced, as the injection is retarded further into the compression stroke ( $\mathrm{SOI}$ at $218^{\circ} \mathrm{ATDC}_{\text {overlap }}$ ). This is more likely due to the in-cylinder mixture stratification. A study of the scatter plot of equivalence ratio and temperature distributions in Fig. 13 reveals that the mixture stratification increases as the injection is retarded. The most stratified mixture charge can be seen with the late injection in the compression stroke, due to less mixing time and relatively weak flow interaction with spray. As shown in Fig. 14, the upward piston movement and the compression bulk flow force a small fraction of fuel droplets to impinge on the exhaust side of the cylinder wall, when the fuel is injected after IVC. Small amounts of both over-rich and very lean mixtures are presented in the combustion chamber at the end of compression stroke, owing to relatively weak compression bulk flow motion. In order to investigate the effect of fuel stratification, a further analysis is carried out on the distributions of equivalence ratio, charge temperature and local heat release rate. As indicated in Fig. 15, at $350^{\circ} \mathrm{CA} \mathrm{ATDC}_{\text {overlap}}$, the presence of more fuel rich pockets with injection at $218^{\circ} \mathrm{ATDC}_{\text {overlap }}$ gives out more heat than that of homogeneous charge with injection at $98^{\circ} \mathrm{ATDC}_{\text {overlap }}$, resulting in earlier start of combustion with late injection at the compression stroke. However, the presence of over-lean and over-rich mixtures due to late injection in the compression stroke decreases the combustion efficiency and hence lowering the IMEP value, as also shown in Table 4.

Figure 16 qualitatively compares the crank angle of 10\% MFB and IMEP for various injection timings from the current modeling studies with the experimental results obtained from a GDI engine with CAI combustion achieved by the negative valve overlap method (Standing et al., 2005). Although the engine used in the experiment is slightly different in compression ratio from the modeled engine, the modeling results show similar trend to that of experiments, confirming the validity of modeling study and its usefulness for better understanding of underlying physical and chemical processes involved in the CAI combustion.

The predicted NOx and soot emissions are presented in Fig. 17. It shows that the early injections produce the highest NOx emission and lowest soot formation, while stratified charge operation increases NOx and soot formations simultaneously. The amount of NOx correlates well with the peak 
charge temperature shown in Table 3 and Table 4. The highest NOx emissions is therefore seen with injection at $-40^{\circ}$ ATDC ${ }_{\text {overlap }}$ in Fig. 17. As also shown in Fig. 17, the soot formation rises rapidly with injections during the negative valve overlap period initially, as some of the fuel is burned in a very rich mixture during the negative valve overlap period, and then the soot formation and oxidation are frozen throughout the intake stroke. However, in the main combustion, the much faster soot oxidation rate with injection during the negative valve overlap period contributes to the lower soot emission than that with injections during the intake and compression strokes, due to the higher combustion temperature. In contrast, the late injection during the compression stroke is characterized with the fastest soot formation rate and slower soot oxidation rate in the main combustion, which in turn results in the highest final soot emission, due to the most stratified charge mixture shown in Fig. 13.

Based on the above studies, the mechanisms of combustion phasing control by injection timing in a lean-burn CAI DI gasoline engine can be summarized as shown in Fig. 18. The factors include the thermal/chemical effects caused by early injection during the negative valve overlap period, or charge cooling effect by injection during the intake stroke, or fuel stratification effect by late injection at the compression stroke. Heat release or thermal effect associated with injection during the negative valve overlap period has a dominant effect on advancing the start of main combustion. The chemical effect is secondary and its presence promotes the first stage of ignition during the compression stroke. However, injection during the negative valve overlap period can also slow down the main combustion process, if the in-cylinder temperature during the recompression process is reduced significantly due to charge cooling effect and hence less or no heat release reactions can take place during the recompression and re-expansion processes. The late injection during the compression stroke can lead to an advanced combustion due to charge stratification, whilst the injection during the intake stroke slows down the start of main combustion by charge cooling effects.

\section{Effect of Split Fuel Injections}

In the previous section, injection timing in the single fuel injection strategy has been shown to have a large effect on combustion characteristics. In order to optimize combustion phasing and engineout emissions, split fuel injection is investigated. The proportion of fuel injected in each of the two injections is varied from $10 \%, 15 \%, 25 \%, 50 \%$ and $75 \%$, while the start of the first and second injections are fixed at $-75^{\circ}$ and $98^{\circ} \mathrm{ATDC}$ overlap, respectively. The total amount of fuel in each engine cycle is kept constant (9 mg), with an overall equivalence ratio around 0.8 . 
The heat release curves during the negative valve overlap period with variable split injection ratios are given in Fig. 19. It is noted that the early heat release during the negative valve overlap period decreases gradually with increasing amount of fuel injected during the recompression process. This could be explained by referring the corresponding temperature during the negative valve overlap period as shown in Table 5. It can be seen that the increased portion of fuel injected during the recompression process leads to significant reduction in temperature, due to fuel evaporation, resulting in smaller early heat release associated with minor combustion during the negative valve overlap period shown in Fig 19 (a) and Fig. 20. On the other hand, more fuel injected during the negative valve overlap promotes the build-up of radical and intermediate species, which leads to higher first stage heat release during compression stroke with 50/50 and 75/25 split injections as shown in Fig. 19 (b). Figure 19 (a) shows that there is a clear relationship between the amount of heat released during the negative valve overlap period and the start of main combustion: the higher the amount of heat released during the negative valve overlap, the earlier the start of main combustion. This indicates that the thermal effect due to early injection during the negative valve overlap period seems to play a predominant role in determining the combustion phasing. Furthermore, comparing 10/90, 15/85 and 25/75 split injections, the earlier start of main combustion with 25/75 split injection is attributed to the higher level of radical and intermediate species present prior to the main combustion shown in Fig. 19(b), since similar amount of heat has been released during the negative valve overlap period as shown in Table 5 and Fig. 19(a).

Table 5 shows the main combustion characteristics and engine performance with different split injection strategies. It is noted that the highest amount of heat release during the negative valve overlap period is obtained with 25/75 split injection, which leads to the most advanced crank angle of $10 \%$ MFB or the start of main combustion, the shortest combustion duration and the highest peak cylinder temperature, and hence the highest NOx emissions. As also shown in Table 5, the pumping loss is at its lowest value with 25/75 split injection. This can be explained by the opposing effects of charge cooling and heat release on the pumping work during the negative valve overlap period. As more fuel is injected into the negative valve overlap period, the charge cooling effect lowers the charge temperature, and hence inhibits the fuel reforming and heat release process as shown in Fig. 19 (a) and Fig. 20, but more importantly the greater charge cooling effect due to the increased first fuel injection causes the cylinder pressure to drop more during the re-expansion stage, and hence higher PMEP. Whilst smaller amount of fuel injection experiences earlier and more heat release during the re-compression stage, which results in larger re-compression work than the re-expansion work during the negative valve overlap, leading to higher PMEP. Although the 25/75 split injection 
has the lowest PMEP, it has the lowest IMEP or highest ISFC. This is due to the fact that ignition and combustion are too advanced (with the crank angle of $50 \%$ MFB just before $\mathrm{TDC}_{\text {comb }}$ ).

As discussed previously, early injection during the negative valve overlap period tends to advance the start of main combustion, whilst injection during the intake stroke leads to higher airflow rate into the cylinder and retarded combustion. In double injection, those two effects will counteract each other. Figure 21 shows that using split injection can improve IMEP and lower soot emissions simultaneously, as compared with the corresponding single injections. By varying the split fueling, the best overall engine performance is obtained with the 50/50 fuel injection split ratio, due to the optimal combustion phasing and relatively low pumping loss, whereas the lowest IMEP and highest ISFC are seen with the single injection at $98^{\circ} \mathrm{ATDC}_{\text {overlap }}$ (the extreme case of split injection). The soot traces of split injections are given in Fig. 22. It can be seen that increasing the amount of fuel injected during the negative valve overlap period dramatically increases the initial soot formation during the negative valve overlap period. In double injection, the split fuel injection with the $75 / 25$ split ratio is characterized with the highest final soot emission, due to higher initial soot formation. In contrast, relatively lower initial soot formation and faster soot oxidation contribute to the lowest soot emission with the split injection ratio of 25/75. As shown in Table 5, the lowest total NOx and soot emissions are obtained with the optimal split injection ratio of 10/90, as compared to all injection cases.

\section{SUMMARY}

Following a sensitivity study on the role of auto-ignition chemistry and high temperature combustion, the effect of single fuel injection timing has been investigated on the CAI combustion with lean mixture. This was followed by a systematic investigation into the effect of split injections on engine performance and emissions characteristics. The conclusions can be summarized as follows:

1. The heat release observed in both experiment and simulation studies during the negative valve overlap period is dominated by the high temperature combustion chemistry.

2. The first heat release seen during the compression stroke is caused by the accumulation of active species and radicals from the low temperature auto-ignition chemistry.

3. In single injection strategy, the mechanisms of combustion phasing control by injection timing can be explained by the thermal/chemical effect caused by early injection during the negative valve overlap period, charge cooling effect by mid injection during the intake stroke, or fuel stratification effect by late injection. 
4. When fuel is injected, during the recompression period, into burned gases of a lean-burn mixture, early heat release resulting from minor combustion has a predominant effect on advancing the start of main heat release process. In addition, intermediate species formed during the negative valve overlap period also contribute to an advanced combustion phasing.

5. When fuel injection takes place in the intake period, more air is inducted into the cylinder and the onset of combustion is slightly delayed as injection timing is retarded.

6. In stratified charge operation associated with late fuel injection in the compression stroke, the creation of a fuel rich zone favours auto-ignition and can be used to promote an early combustion phasing, but with a penalty of higher NOx and soot emissions.

7. For split fuel injection of fixed injection timings at $-75^{\circ}$ and $98^{\circ} \mathrm{ATDC}_{\text {overlap}}$, the best engine performance is obtained with the optimal split injection ratio of 50/50, whilst the lowest total NOx and soot emissions are seen with the split injection ratio of $10 / 90$, as compared to all injections under the constant total fueling in each engine cycle.

\section{ACKNOWLEDGMENTS}

The authors acknowledge the financial support by EPSRC (Engineering and Physical Science Research Council). 


\section{REFERENCES}

Aceves, S.M., Flowers, D.L., Westbrook, C.K., et al., (2000) “ A multi-zone model for prediction of HCCI combustion and emissions", SAE paper 2000-01-0327.

Amsden, A.A., (1999) "KIVA-3V, release 2, improvements to KIVA-3V", Los Alamos National Laboratory Report No. LA-UR-99-915.

Aoyama T., Hattori, Y., Mizuta, J. and Sato, Y., (1996) "An experimental study on premixed-charge compression ignition gasoline engine”, SAE paper 960081.

Borman, C.T., (1975) “Kinetics of pollutant formation and destruction in combustion”, Prog. Energy Combust. Sci., Vol.1, pp. 33-45.

Cao, L., Zhao, H., Jiang, X., and Kalian, N., (2005) "Understanding the influence of valve timings on controlled autoignition combustion in a four-stroke port fuel injection engine”, IMechE Part D: Journal of Automobile Engineering, Vol. 219, pp. 807-823.

Cao, L., Zhao, H., Jiang, X. and Kalian, N., (2006) "Investigation into the effect of injection timing on stoichiometric and lean CAI operations in a 4-stroke GDI engine”, SAE paper 2006-01-0417.

Christensen, M., Hultqvist, A., and Johansson, B., (1999) "Demonstrating the multi-fuel capability of a homogeneous charge compression ignition engine with variable compression ratio”, SAE paper 1999-01-3679.

Halstead, M., Prothero, A., and Quinn, C.P., (1977) "The Autoignition of Hydro-Carbon Fuels at High Temperatures and Pressures_Fitting of a Mathematical Model”, Combustion and Flame, Vol. 30, pp. 45-60.

Han, Z. and Reitz, R.D., (1997) "A temperature wall function formulation for variable-density turbulence flows with application to engine convective heat transfer modeling”, International Journal of Heat and Mass Transfer, 40 (3), pp. 613-625.

Han Z., Fan L., and Reitz, R.D., (1997) "Multidimensional Modeling of Spray Atomization and Air-Fuel Mixing in a Direct-Injection Spark-Ignition Engine”, SAE Paper 970884.

Haraldsson, G., Tunestal, P. and Johansson, B., (2004) "HCCI closed-loop combustion control using fast thermal management”, SAE paper 2004-01-0943.

Heywood, J.B., (1988) “Internal combustion engine fundamentals”, McGraw-Hill Book Company, ISBN 0-07100499-8, pp. 574.

Hiroyasu, H. and Nishida, K., (1989) "Simplified three-dimensional modelling of mixture formation and combustion in a DI diesel engine”, SAE paper 890269. 
Kong, S. C., Han Z., and Reitz, R.D., (1995) "The Development and Application of a Diesel Ignition and Combustion Model for Multidimensional Engine Simulation”, SAE Paper 950278.

Kahaaina, N., Simon, A.J., Caton, P.A. et al., (2001) "Use of dynamic valving to achieve residual-affected combustion”, SAE paper 2001-01-0549.

Koopmans, L., Ogink, R. and Denbratt, I., (2003) "Direct gasoline injection in the negative valve overlap of a homogeneous charge compression ignition engine”, JSAE 20030195.

Kuo, T.W., and Reitz, R.D., (1992) "Three-Dimensional Computations of Combustion in Premixed-Charge and Direct-Injected Two-Stroke Engines”, SAE Paper 920425.

Law, D., Kemp, D., and Allen, J., (2001) “Controlled combustion in an IC engine with fully variable valve train”, SAE paper 2001-01-0251.

Lavy, J., Dabadie, J.C., Angelberger, C., Duret, P., Willand, J., Juretzka, A., Schaflein, J., Ma, T., Lendresse, Y., Satre, A., Schulz, C., Kramer, H., Zhao, H., and Damiano, L., (2000) "Innovative Ultra-low NOx controlled auto-ignition combustion process for gasoline engines: the 4-SPACE project”, SAE paper 2000-01-1873.

Li, J., Zhao, H. and Ladommatos, N., (2001) "Research and development of controlled auto-ignition combustion in a 4-stroke multi-cylinder gasoline engine”, SAE paper 2001-01-3608.

Marriott, C.D., and Reitz, R.D., (2002) “Experimental investigation of direct injection-gasoline for premixed compression ignited combustion phasing control”, SAE paper 2002-01-0418.

Nagle, J. and Strickland-Constable, R.F., (1962) “Oxidation of carbon between 1000-2000 C”, Proc. of the fifth carbon conf., Vol.1, pp. 154.

Oakley, A., Zhao, H., Ma, T., and Ladommatos, N., (2001) "Experimental studies on controlled auto-ignition (CAI) combustion of gasoline in a 4-stroke engine”, SAE paper 2001-01-1030.

Onishi, S., Hong Jo S., Shoda, K., Do Jo, P. and Kato, S., (1979) “Active thermo-atmosphere combustion ATAC) - A new combustion process for internal combustion engines”, SAE paper 790507.

Rutland, C.J., Echhause, J., Hampson, G., et al., (1994) “Toward predictive modelling of diesel engine intake flow, combustion, and emissions”, SAE paper 941897.

Ryan III, T. W., and Callahan, T.J., (1996) “Homogeneous charge compression ignition of diesel fuel”, SAE paper 961160 .

Standing R., (2005) “Controlled auto-ignition in a multi-cylinder direct injection gasoline engine”, PhD thesis, Brunel university, UK.

Urushihara, T., Hiraya, K. et al, (2003) "Expansion of HCCI operating region by the combination of direct fuel injection , negative valve overlap and internal fuel reformation”, SAE paper 2003-01-0749.

Willand, J., Nieberding, R., Vent, G. et al., (1998) “The knocking syndrome-its cure and its potential”, SAE paper 982483.

Wolters, P., Salber, W., Geiger, J., et al., (2003) “Controlled auto-ignition combustion process with an electromechanical valve train”, SAE paper 2003-01-0032. 
Yang, J., Culp, T. and Kenny, T. et al (2002) "Development of a gasoline engine system using HCCI technology-the concept and the test results”, SAE paper 2002-01-2832.

Zhao, H., Xie, H. and Peng, z., (2005) "Effect of recycled burned gases on homogeneous charge compression ignition combustion”, Combustion Science and Technology, Vol. 177, pp. 1863-1882. 
Table 1 Engine specification and its operating conditions.

\begin{tabular}{|c|c|}
\hline Engine Type & Ford 1.7L Zetec \\
\hline Bore (mm) & 80 \\
\hline Stroke (mm) & 83.5 \\
\hline Displacement $\left(\mathrm{cm}^{3}\right)$ & 1679 \\
\hline Compression ratio & 10.3 \\
\hline Engine Speed & $1500 \mathrm{rpm}$ \\
\hline Valve train (4-Valve) & $\begin{array}{l}\text { EVO: }-195^{\circ} \mathrm{CA} \quad \text { ATDC }_{\text {overlap }} \\
\text { EVC: }-85^{\circ} \mathrm{CA} \text { ATDC } \text { overlap }^{\circ} \\
\text { IVO: } 88^{\circ} \mathrm{CA} \text { ATDC }_{\text {overlap }} \\
\text { IVC: } 208^{\circ} \mathrm{CA} \quad \text { ATDC }_{\text {overlap }}\end{array}$ \\
\hline Fuel supply system & GDI, Hollow cone swirl spray injector \\
\hline Spray cone angle & $70^{\circ}$ \\
\hline Start of Injection (SOI) & $-75^{\circ},-40^{\circ},-20^{\circ}, 0^{\circ}, 98^{\circ}, 150^{\circ}, 218^{\circ} \mathrm{CA} \mathrm{ATDC}_{\text {overlap }}$ \\
\hline Injection pressure (MPa) & 10 \\
\hline Injection duration & $30^{\circ} \mathrm{CA}(9 \mathrm{mg})$ \\
\hline Equivalence ratio & $\sim 0.8$ \\
\hline Intake temperature (K) & 320 \\
\hline
\end{tabular}

Table 2 Effect of fuel injection on CAI engine performance.

\begin{tabular}{|c|c|c|c|c|c|c|c|}
\hline & $\begin{array}{l}\text { SOI at - } \\
\mathbf{7 5}^{\circ} \\
\text { ATDC }\end{array}$ & $\begin{array}{l}\text { SOI at }- \\
\mathbf{4 0}^{\circ} \\
\text { ATDC }\end{array}$ & $\begin{array}{l}\text { SOI at } \\
-\mathbf{2 0}^{\circ} \\
\text { ATDC }\end{array}$ & $\begin{array}{l}\text { SOI at } \\
\text { TDC }\end{array}$ & $\begin{array}{l}\text { SOI at } \\
\mathbf{9 8}^{\circ} \\
\text { ATDC }^{\circ}\end{array}$ & $\begin{array}{l}\text { SOI at } \\
\mathbf{1 5 0}^{\circ} \\
\text { ATDC }^{\circ}\end{array}$ & $\begin{array}{l}\text { SOI at } \\
\mathbf{2 1 8}^{\circ} \\
\text { ATDC }^{\circ}\end{array}$ \\
\hline Airflow rate [g/s] & 7.70 & 7.22 & 7.31 & 7.85 & 8.03 & 7.91 & 7.61 \\
\hline Temp. at $\mathbf{3 4 0}^{\circ}$ ATDC [K] & 964 & 979 & 974 & 962 & 956 & 954 & 946 \\
\hline PMEP [MPa] & -0.0353 & -0.0376 & -0.0364 & -0.0395 & -0.0331 & -0.0334 & -0.0338 \\
\hline
\end{tabular}


Table 3 Combustion characteristics and engine performance with injections during the negative valve overlap period

\begin{tabular}{|l|c|c|c|c|}
\hline & $\begin{array}{c}\text { SOI at }-75 \\
\text { ATDC }\end{array}$ & $\begin{array}{c}\text { SOI at }-40 \\
\text { ATDC }\end{array}$ & $\begin{array}{c}\text { SOI at }-20 \\
\text { ATDC }\end{array}$ & $\begin{array}{c}\text { SOI at } \\
\text { TDC }\end{array}$ \\
\hline $10 \% \mathrm{MFB}\left[{ }^{\circ} \mathrm{CA}\right]$ & 360.0 & 353.4 & 354.8 & 360.8 \\
\hline $50 \% \mathrm{MFB}\left[{ }^{\circ} \mathrm{CA}\right]$ & 366.6 & 358.5 & 360.2 & 366.8 \\
\hline $90 \% \mathrm{MFB}\left[{ }^{\circ} \mathrm{CA}\right]$ & 376.0 & 367.0 & 368.0 & 375.5 \\
\hline $10-50 \% \mathrm{MFB}\left[{ }^{\circ} \mathrm{CA}\right]$ & 6.6 & 5.1 & 5.4 & 6.0 \\
\hline $50-90 \% \mathrm{MFB}\left[{ }^{\circ} \mathrm{CA}\right]$ & 9.4 & 8.5 & 7.8 & 8.7 \\
\hline $10-90 \% \mathrm{MFB}\left[{ }^{\circ} \mathrm{CA}\right]$ & 16.0 & 13.6 & 13.2 & 14.7 \\
\hline Pmax $[\mathrm{MPa}]$ & 3.21 & 3.71 & 3.62 & 3.19 \\
\hline Tmax $[\mathrm{K}]$ & 1880 & 2012 & 1987 & 1895 \\
\hline Net IMEP $[\mathrm{MPa}]$ & 0.311 & 0.287 & 0.291 & 0.305 \\
\hline ISFC $[\mathrm{g} / \mathrm{KW} \cdot \mathrm{h}]$ & 248 & 269 & 265 & 253 \\
\hline Comb. efficiency & 0.95 & 0.95 & 0.94 & 0.94 \\
\hline ISNOx [g/Kg.fuel] & 0.083 & 0.892 & 0.653 & 0.239 \\
\hline Soot $[\mathrm{g} / \mathrm{Kg} \cdot$ fuel] & 0.883 & 0.595 & 0.493 & 0.531 \\
\hline
\end{tabular}

Table 4 Combustion characteristics and engine performance with injections during the intake and compression strokes.

\begin{tabular}{|l|c|c|c|}
\hline & $\begin{array}{c}\text { SOI at 98 } \\
\text { ATDC }\end{array}$ & $\begin{array}{c}\text { SOI at 150 } \\
\text { ATDC }\end{array}$ & $\begin{array}{c}\text { SOI at 218 } \\
\text { ATDC }\end{array}$ \\
\hline $10 \%$ MFB $\left[{ }^{\circ} \mathrm{CA}\right]$ & 364.8 & 365.2 & 360.3 \\
\hline $50 \% \mathrm{MFB}\left[{ }^{\circ} \mathrm{CA}\right]$ & 373.6 & 373.3 & 368.3 \\
\hline $90 \% \mathrm{MFB}\left[{ }^{\circ} \mathrm{CA}\right]$ & 386.0 & 387.8 & 379.0 \\
\hline $10-50 \% \mathrm{MFB}\left[{ }^{\circ} \mathrm{CA}\right]$ & 8.8 & 8.1 & 8.0 \\
\hline $50-90 \% \mathrm{MFB}\left[{ }^{\circ} \mathrm{CA}\right]$ & 12.4 & 14.5 & 10.7 \\
\hline $10-90 \% \mathrm{MFB}\left[{ }^{\circ} \mathrm{CA}\right]$ & 21.2 & 22.6 & 18.7 \\
\hline Pmax $[\mathrm{MPa}]$ & 2.61 & 2.57 & 2.86 \\
\hline Tmax $[\mathrm{K}]$ & 1746 & 1707 & 1763 \\
\hline Net IMEP $[\mathrm{MPa}]$ & 0.304 & 0.292 & 0.279 \\
\hline ISFC $[\mathrm{g} / \mathrm{KW} \cdot \mathrm{h}]$ & 254 & 264 & 276 \\
\hline Comb. efficiency & 0.93 & 0.90 & 0.85 \\
\hline ISNOx $[\mathrm{g} / \mathrm{Kg} \cdot f u e l]$ & 0.0232 & 0.0383 & 0.0542 \\
\hline Soot $[\mathrm{g} / \mathrm{Kg} \cdot f u e l]$ & 0.958 & 1.313 & 2.210 \\
\hline Temp. at $340^{\circ} \mathrm{ATDC}[\mathrm{K}]$ & 967 & 965 & 957 \\
\hline
\end{tabular}


Table 5 Combustion characteristics and engine performance with variable split injection ratios.

\begin{tabular}{|l|c|c|c|c|c|}
\hline & $\begin{array}{c}\text { Inject. ratio } \\
10 / 90\end{array}$ & $\begin{array}{c}\text { Inject. ratio } \\
15 / 85\end{array}$ & $\begin{array}{c}\text { Inject. ratio } \\
25 / 75\end{array}$ & $\begin{array}{c}\text { Inject. ratio } \\
50 / 50\end{array}$ & $\begin{array}{c}\text { Inject. ratio } \\
75 / 25\end{array}$ \\
\hline Early heat release/total & 0.055 & 0.056 & 0.060 & 0.036 & 0.021 \\
\hline Temp. at TDC ${ }_{\text {overlap }}[\mathrm{K}]$ & 1452 & 1443 & 1413 & 1298 & 1218 \\
\hline $10 \%$ MFB $\left[{ }^{\circ} \mathrm{CA}\right]$ & 355.5 & 354.5 & 353.5 & 358.3 & 360.4 \\
\hline $50 \%$ MFB $\left[{ }^{\circ} \mathrm{CA}\right]$ & 361.5 & 360.5 & 359.4 & 364.8 & 367.1 \\
\hline $90 \%$ MFB $\left[{ }^{\circ} \mathrm{CA}\right]$ & 372.1 & 371.0 & 369.1 & 375.0 & 377.4 \\
\hline $10-50 \%$ MFB $\left[{ }^{\circ} \mathrm{CA}\right]$ & 6.0 & 6.0 & 5.9 & 6.5 & 6.7 \\
\hline $50-90 \%$ MFB $\left[{ }^{\circ} \mathrm{CA}\right]$ & 10.6 & 10.5 & 9.7 & 10.2 & 10.3 \\
\hline $10-90 \% \mathrm{MFB}\left[{ }^{\circ} \mathrm{CA}\right]$ & 16.6 & 16.5 & 15.6 & 16.7 & 17.0 \\
\hline Pmax $[\mathrm{MPa}]$ & 3.50 & 3.55 & 3.61 & 3.31 & 3.15 \\
\hline Tmax $[\mathrm{K}]$ & 1965 & 1979 & 2000 & 1912 & 1866 \\
\hline PMEP $[\mathrm{MPa}]$ & -0.0160 & -0.0145 & -0.0133 & -0.0241 & -0.0329 \\
\hline Net IMEP $[\mathrm{MPa}]$ & 0.313 & 0.310 & 0.309 & 0.314 & 0.311 \\
\hline ISFC [g/KW·h] & 247 & 249 & 250 & 246 & 248 \\
\hline Comb. efficiency & 0.96 & 0.96 & 0.96 & 0.96 & 0.96 \\
\hline ISNOx [g/Kg.fuel] & 0.312 & 0.365 & 0.452 & 0.146 & 0.080 \\
\hline Soot [g/kg.fuel] & 0.175 & 0.168 & 0.164 & 0.636 & 1.003 \\
\hline
\end{tabular}




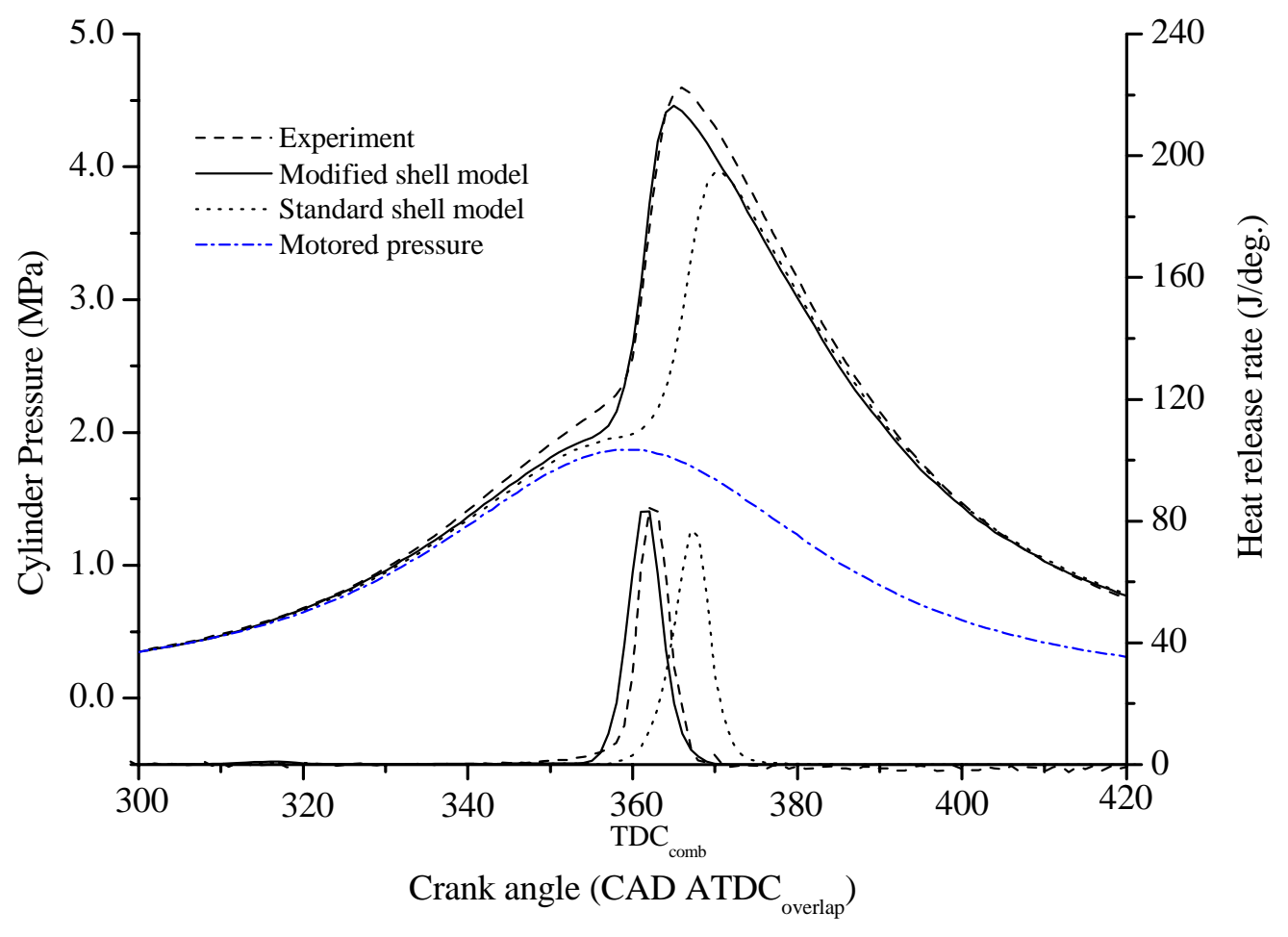

Fig. 1 Comparison of pressure and heat release rate among the experimental data ( $\mathrm{Li}, 2001)$ and predicted values with the standard and modified Shell models. ( $\phi=1, \mathrm{RPM}=1500$, EVC at $-85^{\circ} \mathrm{ATDC}_{\text {overlap }}$, IVO at $88^{\circ} \mathrm{ATDC}_{\text {overlap }}$ )

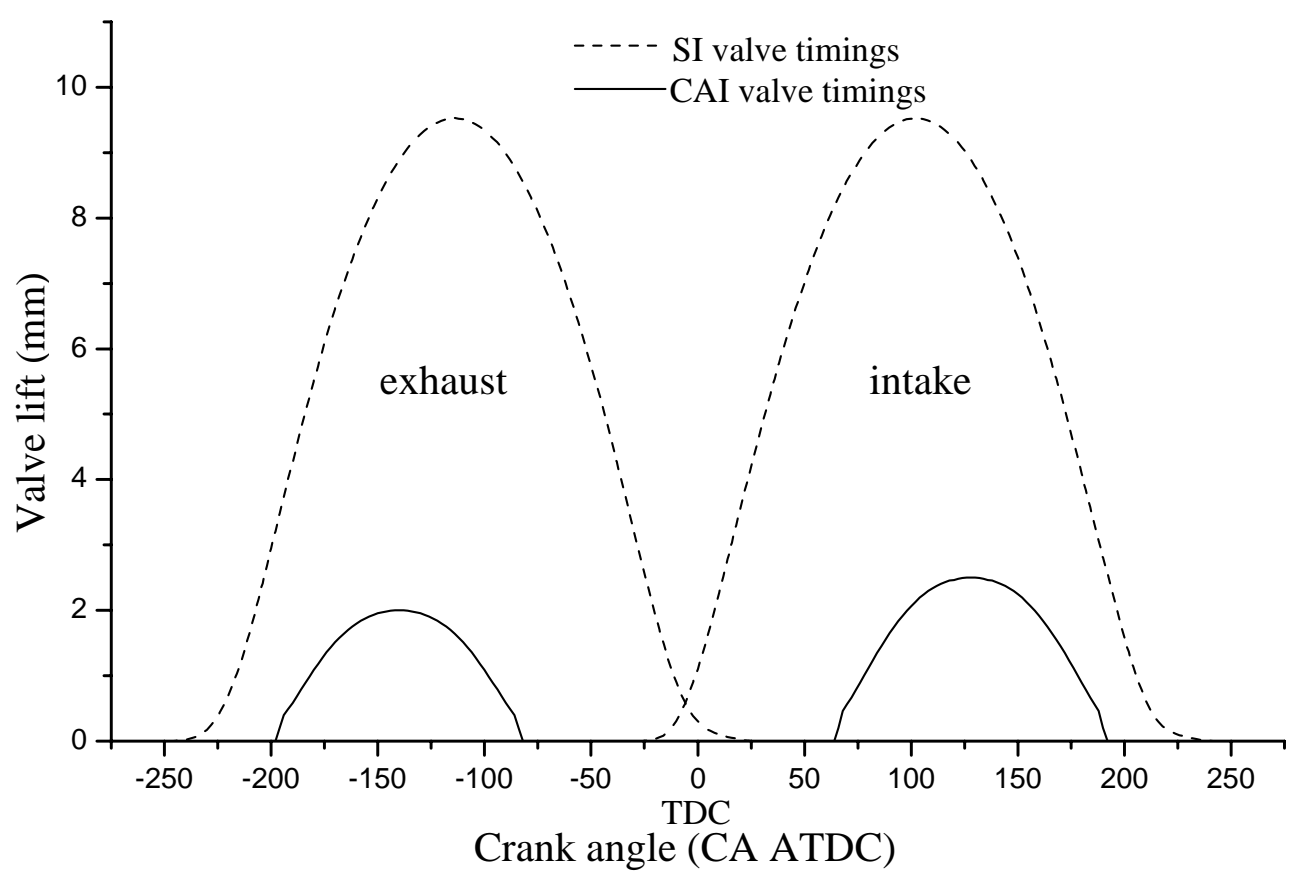

Fig. 2 Typical CAI and SI valve timings diagrams 


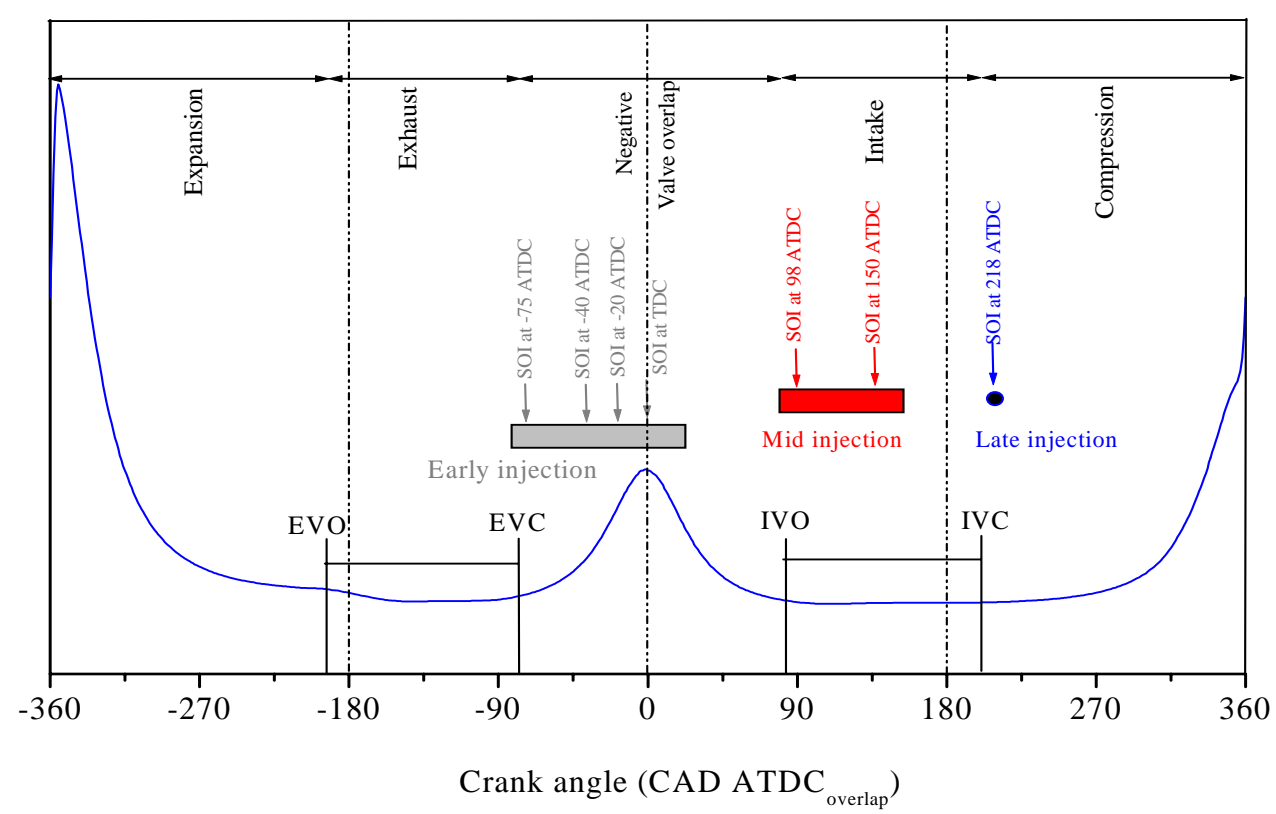

Fig. 3 Injection timings for single injection strategy in a DI CAI engine

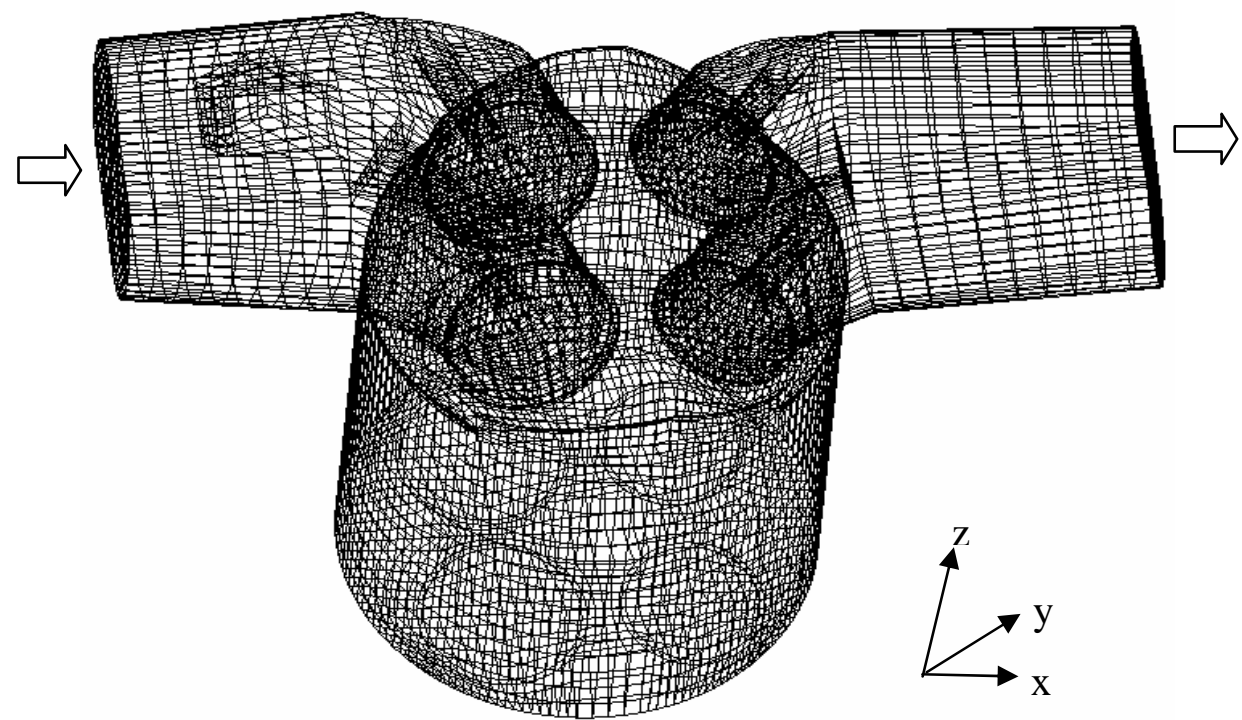

Fig. 4 3D numerical grid for the Ford engine 


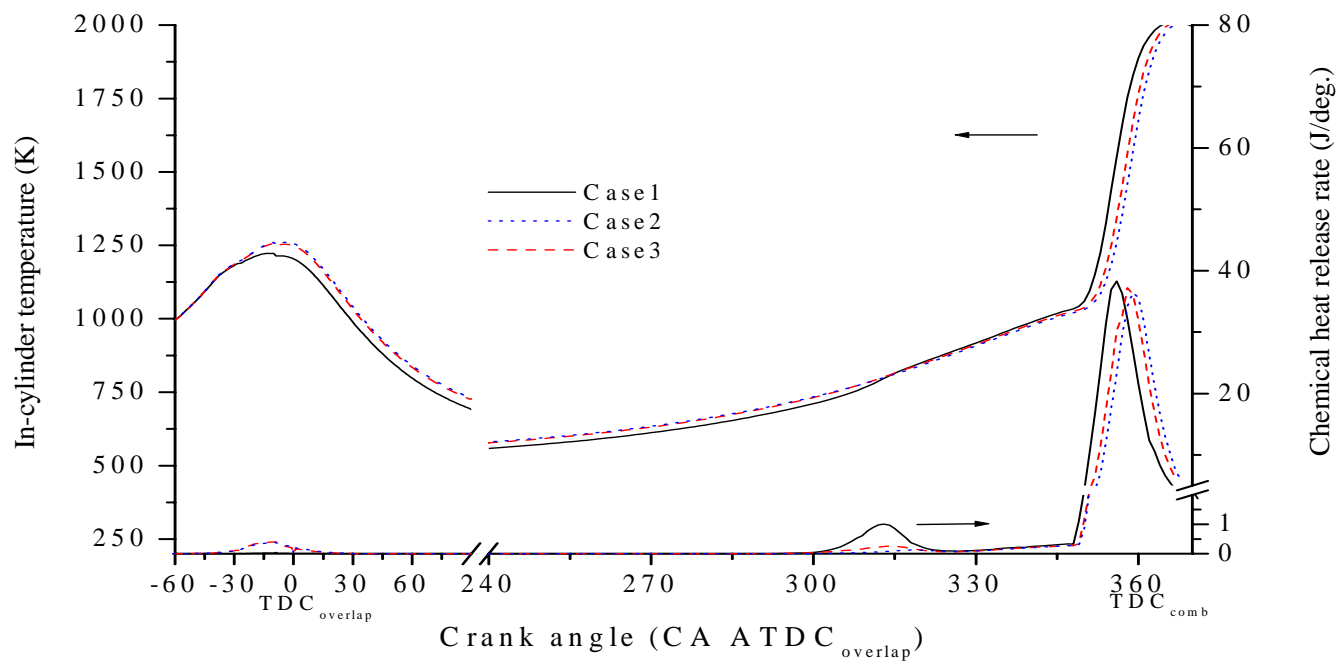

(a) predicted temperature and heat release traces

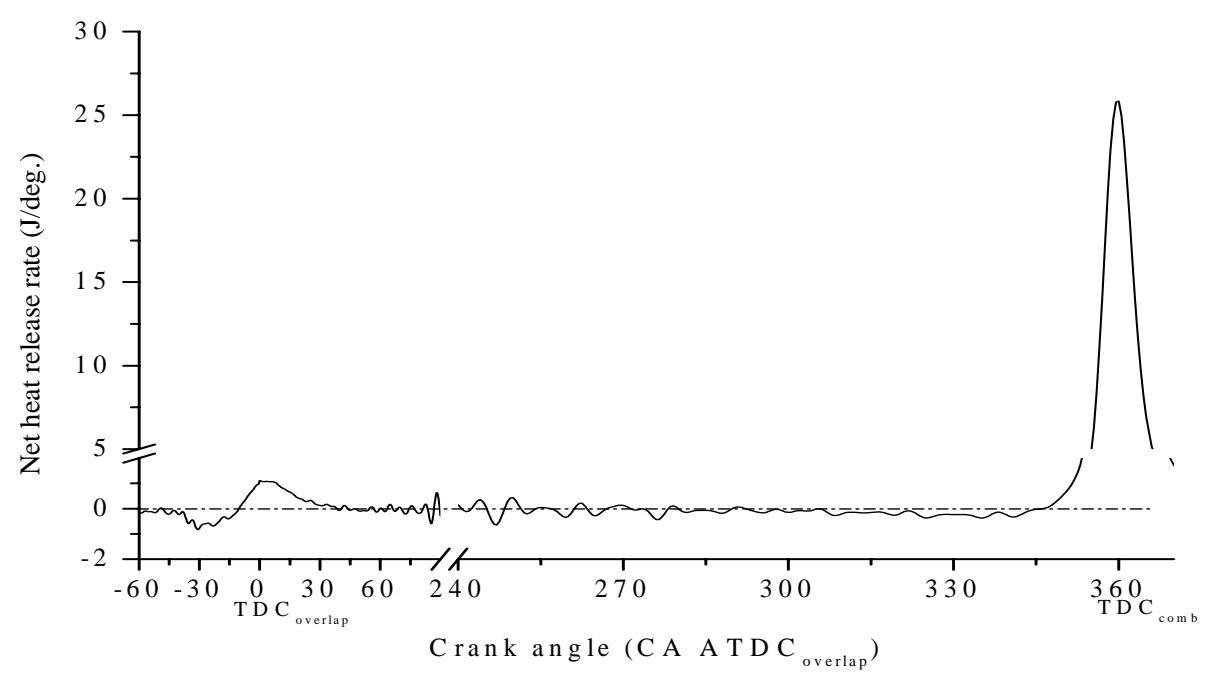

(b) derived net heat release rate from measured pressure trace in a DI gasoline engine [Standing, 2005]

Fig. 5 Predicted temperature and heat release profiles of all three cases with injection at $-40^{\circ} \mathrm{ATDC}_{\text {overlap }}$ 


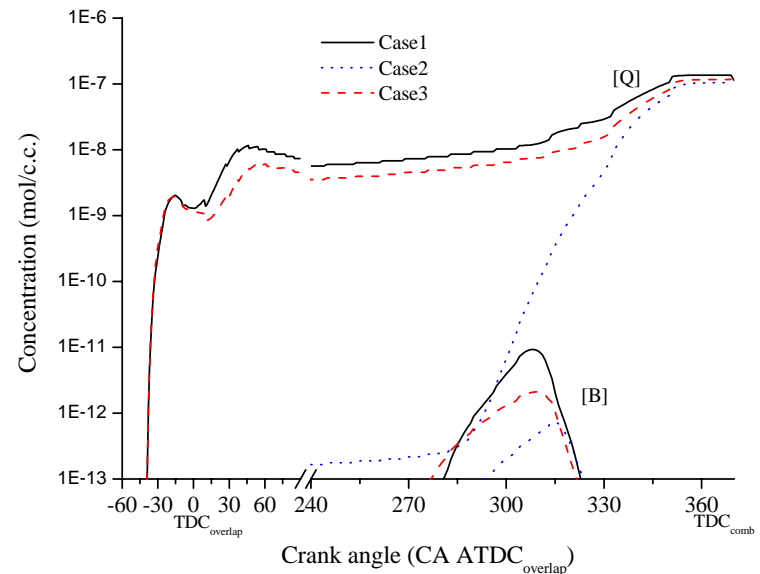

(a)

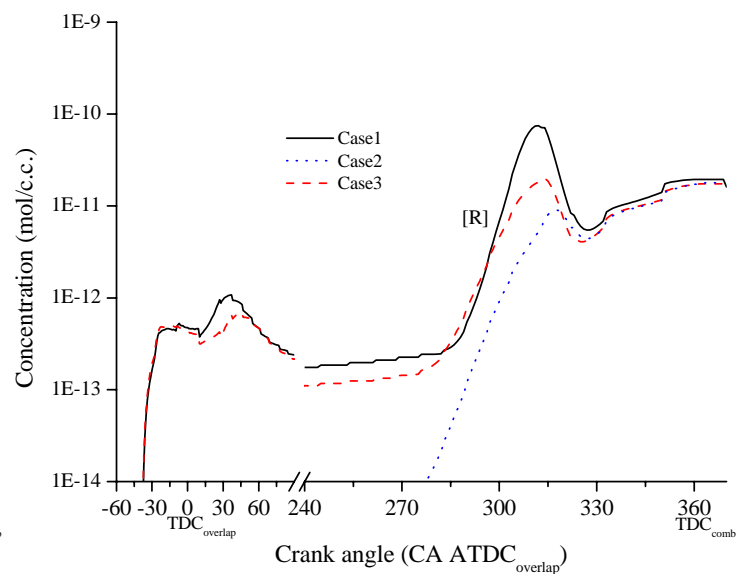

(b)

Fig. 6 Predicted radical/intermediate species traces of all three cases.

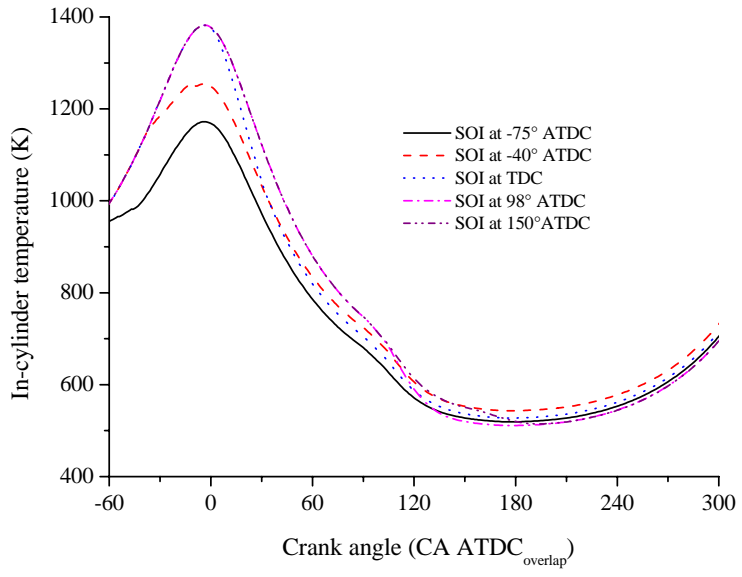

(a) temperature history

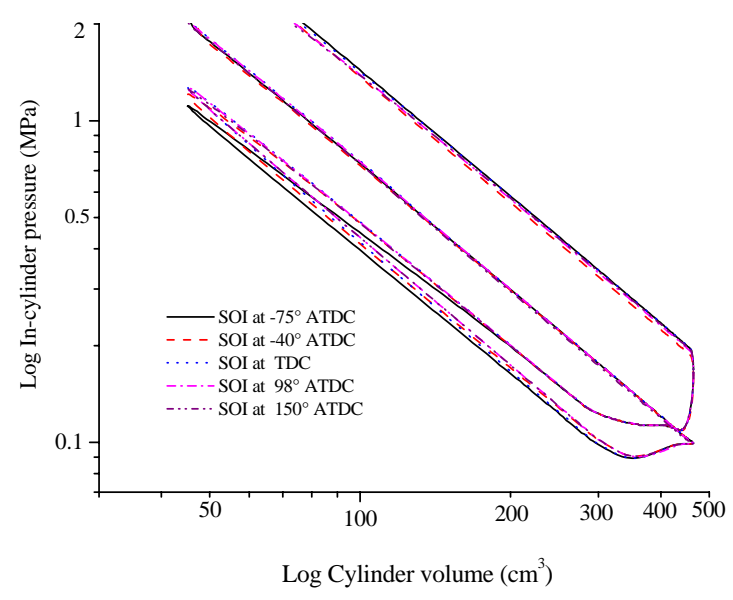

(b) $\log \mathrm{P}-\mathrm{V}$ diagram during $\mathrm{NVO}$

Fig. 7 Effect of charge cooling during the negative valve overlap and intake periods 

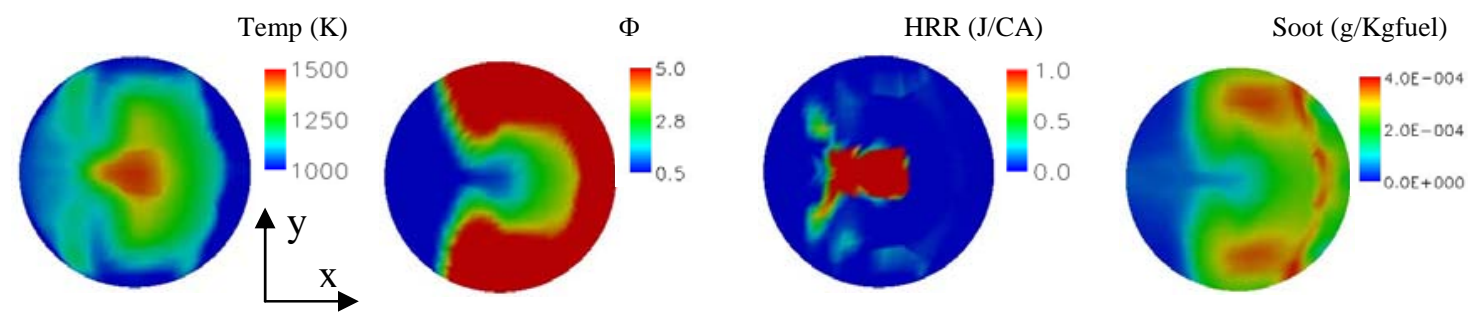

(a) $\mathrm{TDC}_{\text {overlap }}$ (Case of SOI at $-75^{\circ}$ ATDC)
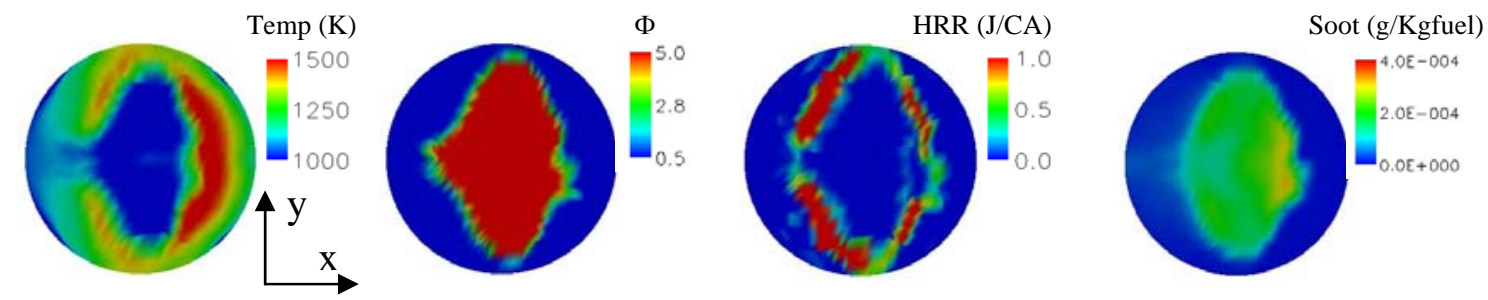

(b) $\mathrm{TDC}_{\text {overlap }}$ (Case of SOI at $-40^{\circ} \mathrm{ATDC}$ )
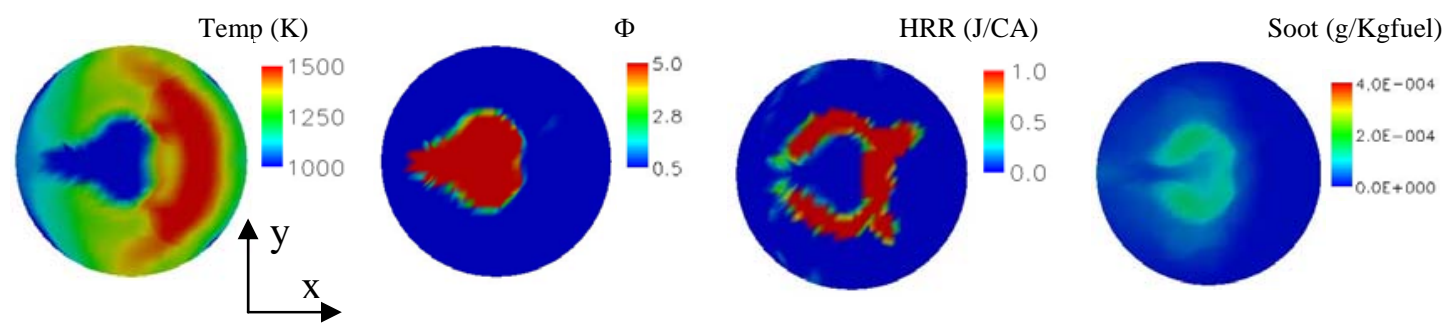

(c) $\mathrm{TDC}_{\text {overlap }}$ (Case of SOI at $-20^{\circ} \mathrm{ATDC}$ )

Fig. 8 Distributions of temperature, equivalence ratio, heat release rate and soot at $\mathrm{TDC}_{\text {overlap }}$ for the cases of SOI at $-75^{\circ},-40^{\circ}$ and $-20^{\circ}$ ATDC. 


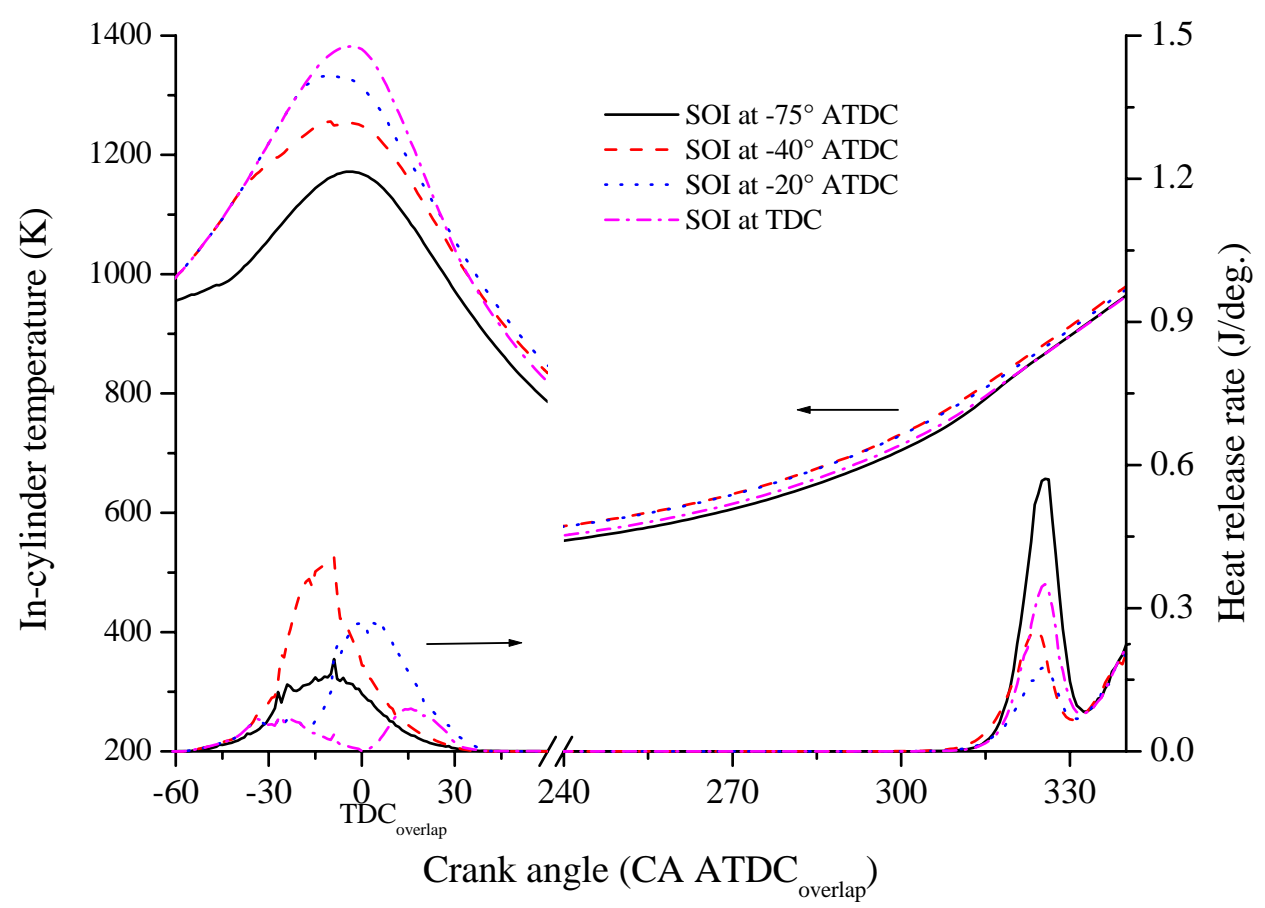

Fig. 9 Heat release rate and temperature traces during the negative valve overlap and compression processes.

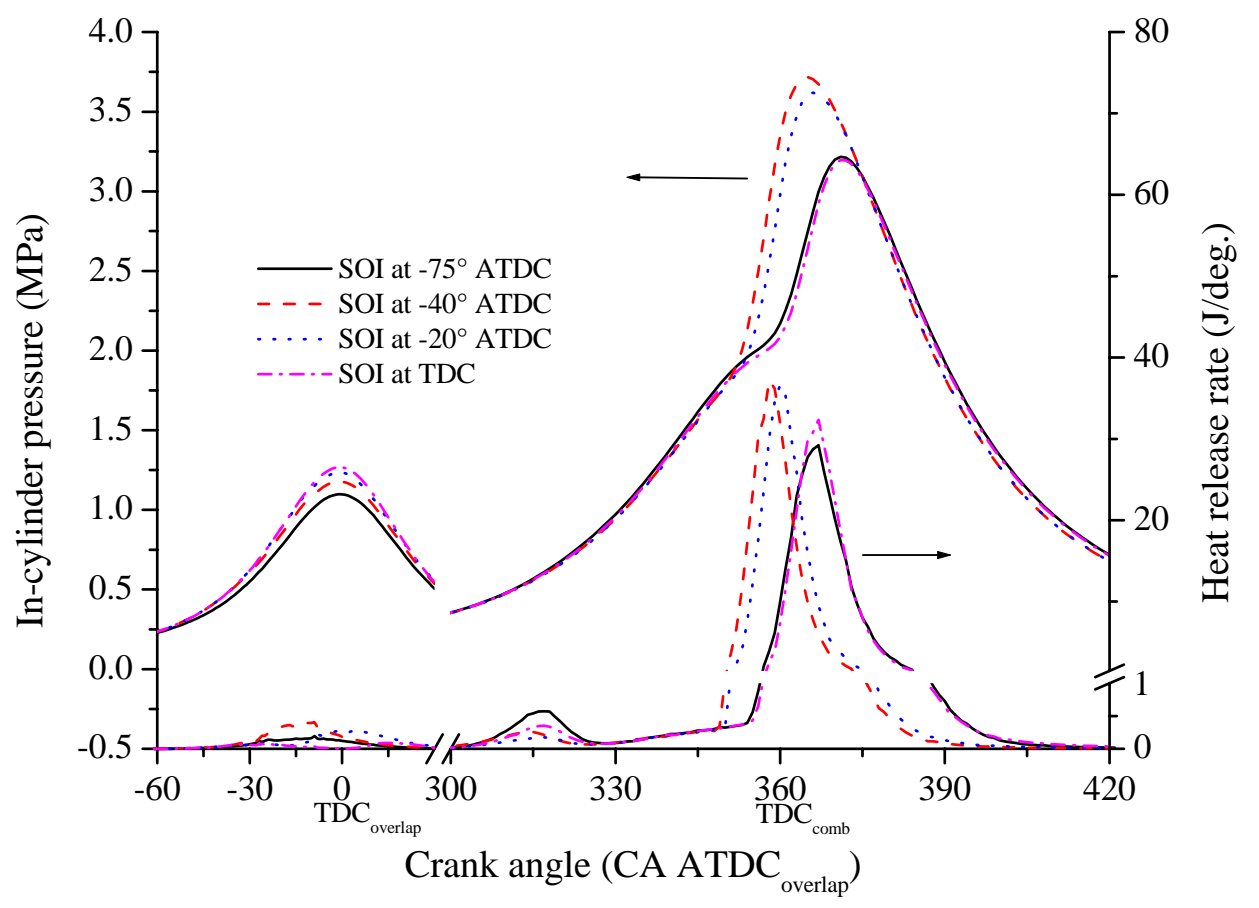

Fig. 10 Pressure and heat release rate traces with injections during the negative valve overlap period. 


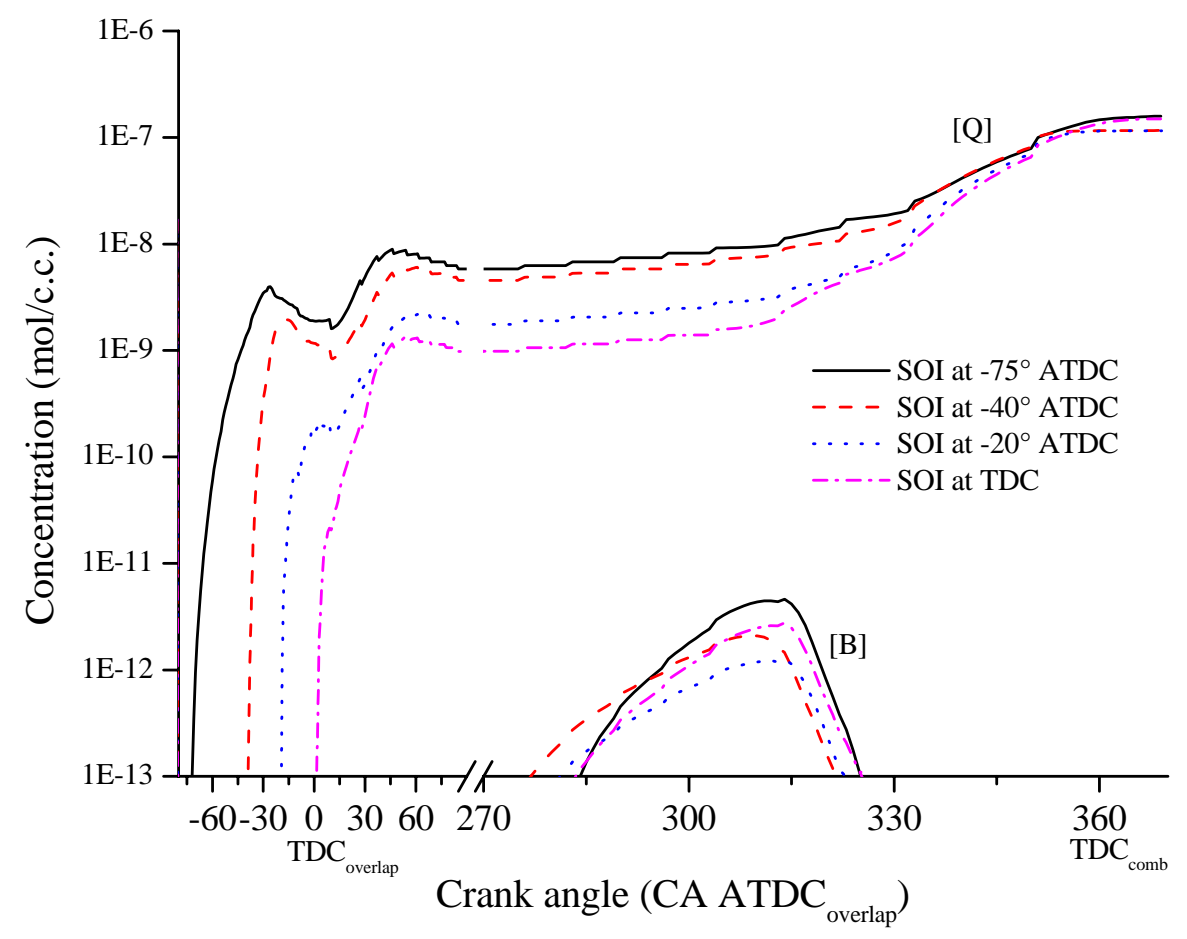

Fig.11 Radical/intermediate species traces with injections during the negative valve overlap period.

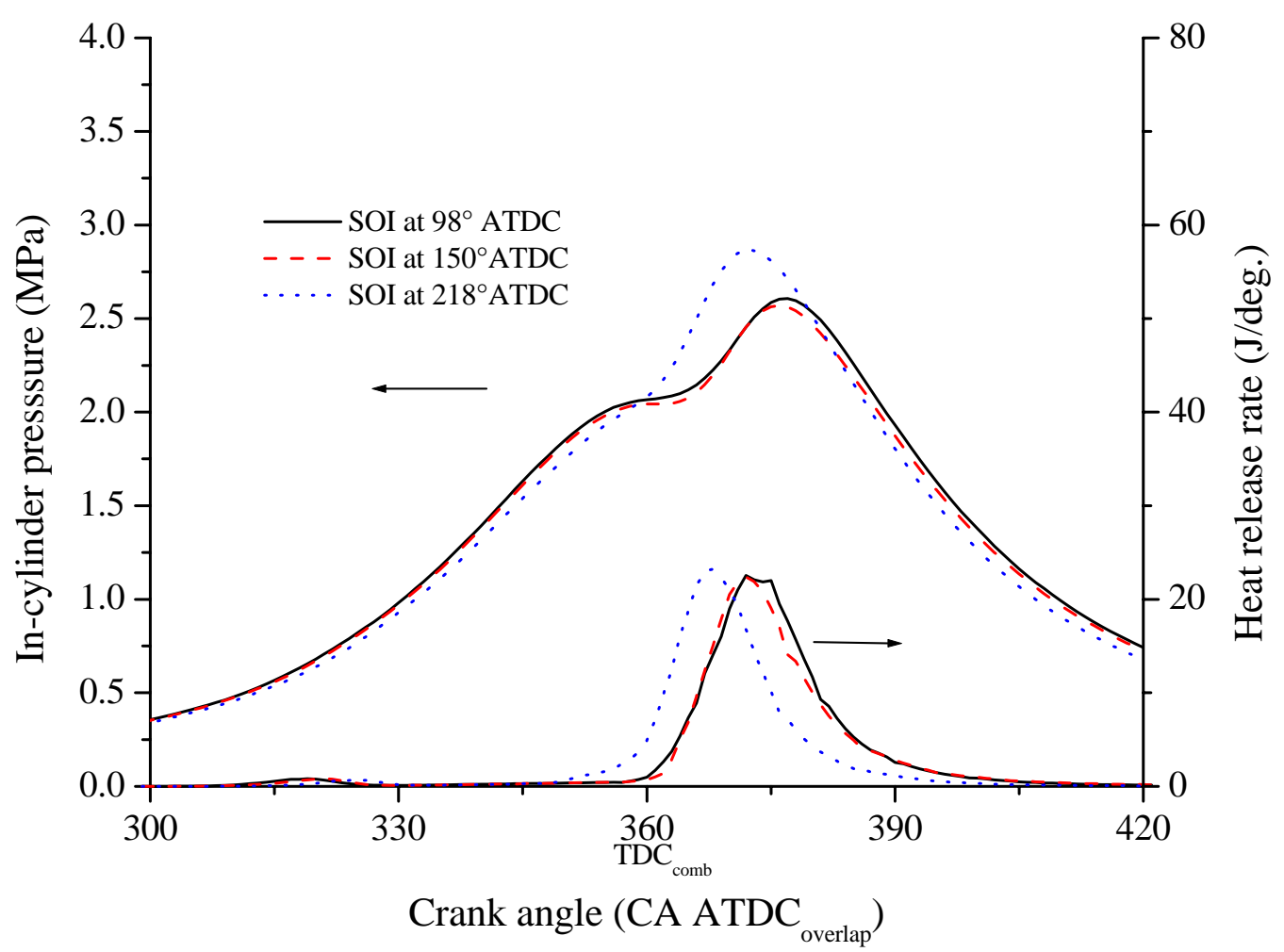

Fig. 12 Pressure and heat release rate profiles of the mid and late injections during the intake and compression 


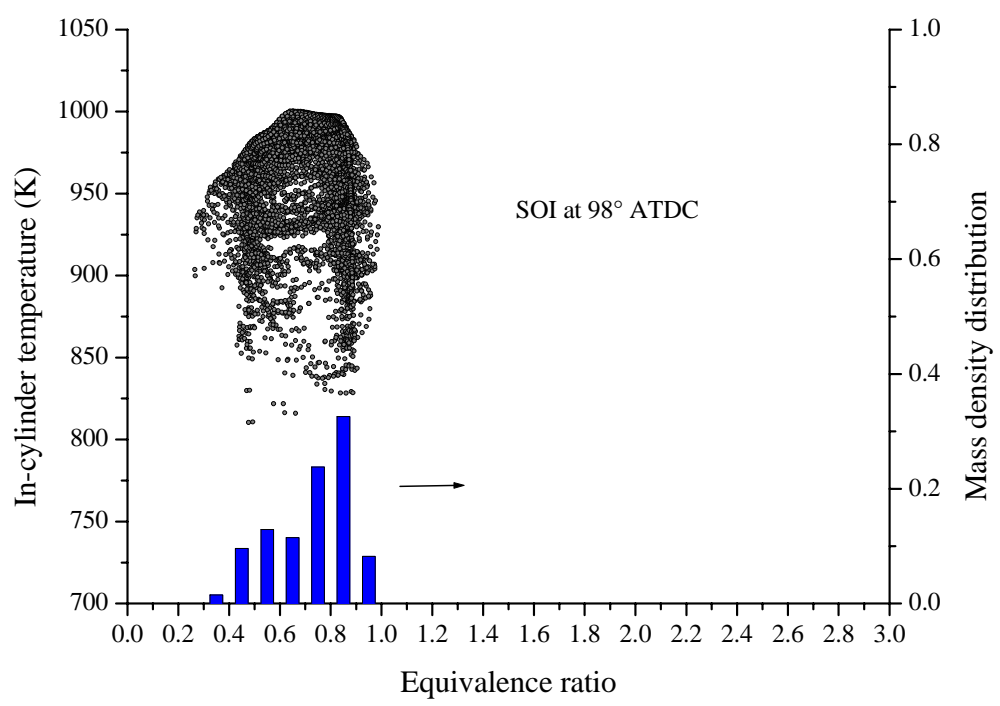

(a)

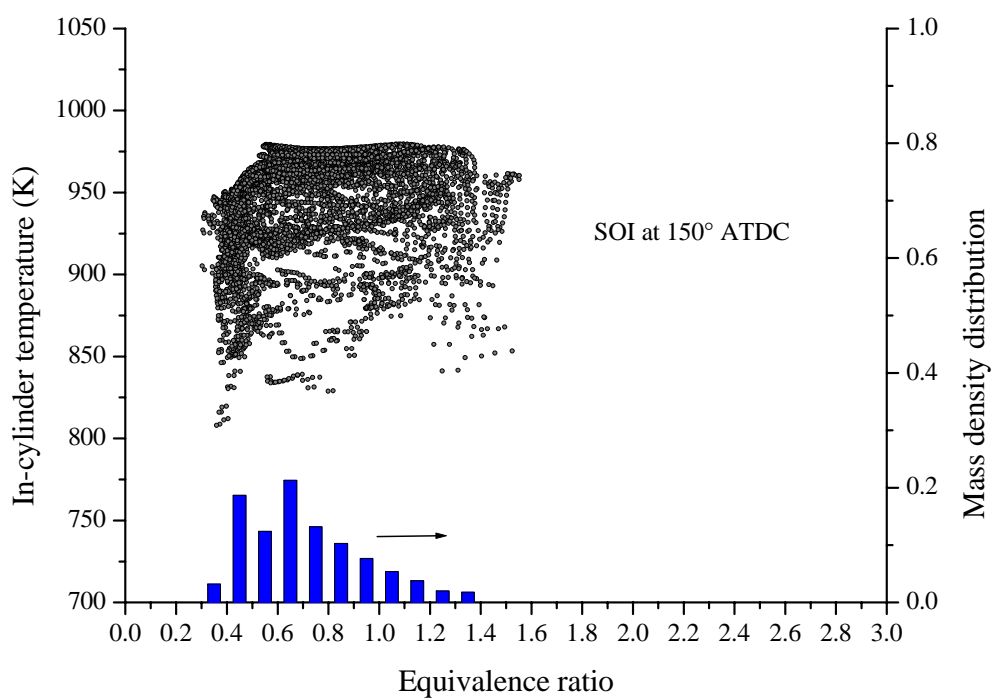

(b)

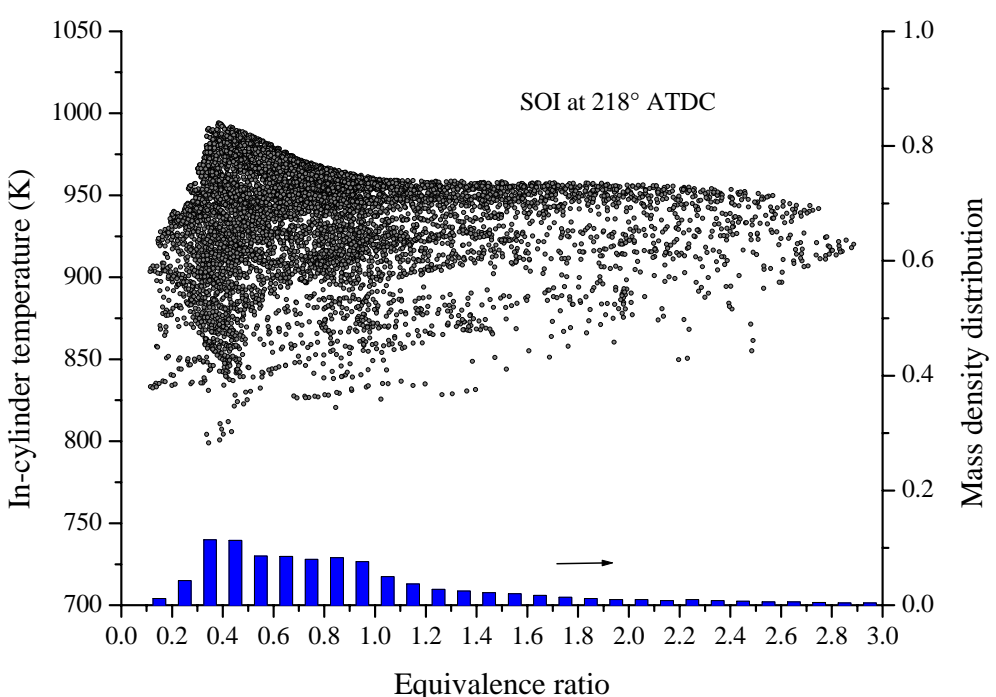

(c)

Fig.13 Equivalence ratio-temperature distribution at $340^{\circ} \mathrm{ATDC}_{\text {overlap }}$ for the cases with injections at the intake and compression strokes. 


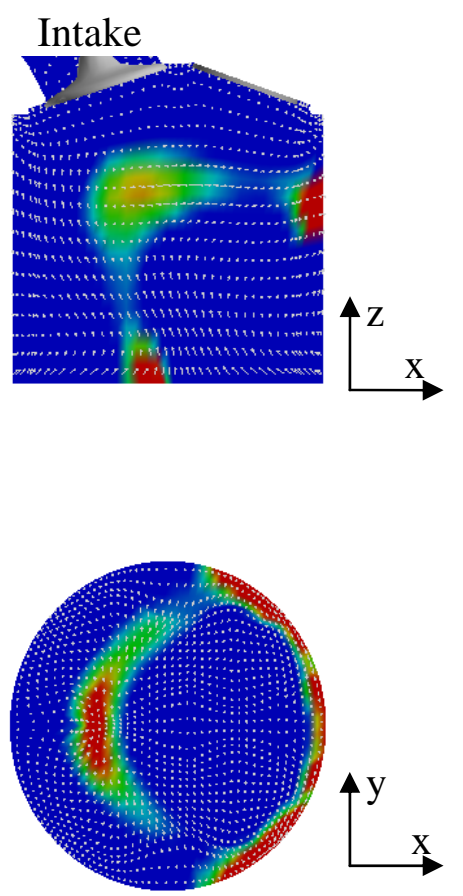

(a) $240^{\circ} \mathrm{ATDC}$
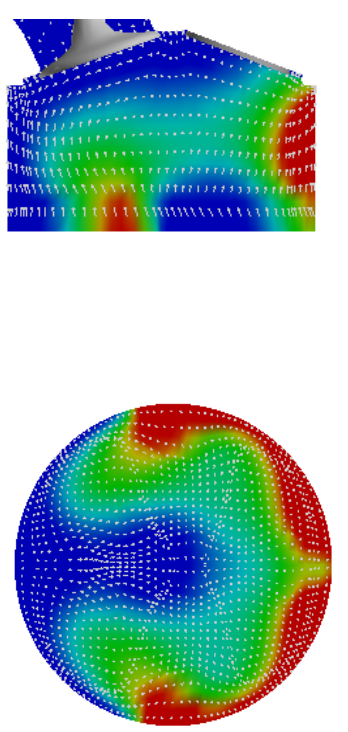

(b) $290^{\circ} \mathrm{ATDC}$
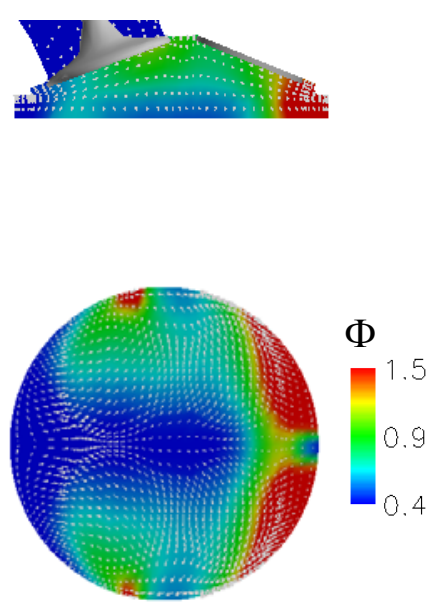

(c) $340^{\circ} \mathrm{ATDC}$

Fig. 14 Computed spatial distribution of equivalence ratio for the case with injection at $218^{\circ}$ ATDC. Top: the $\mathrm{x}-\mathrm{z}$ plane is the central vertical plane of the intake valve. Bottom: the $\mathrm{x}-\mathrm{y}$ plane is the middle plane along the $\mathrm{z}$-axis.
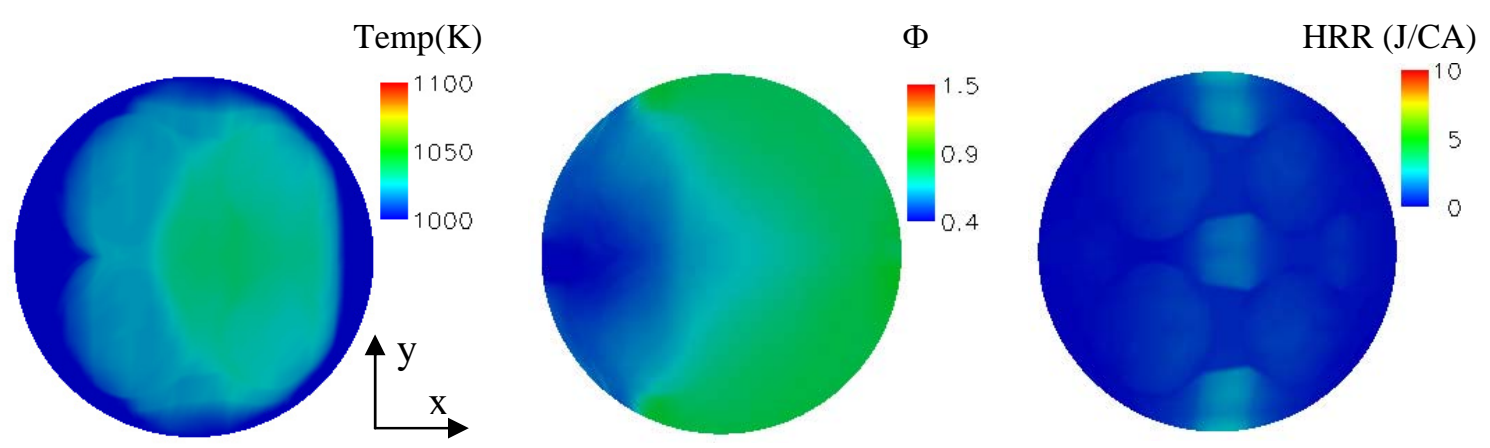

(a) SOI at $98^{\circ} \mathrm{ATDC}_{\text {overlap }}$
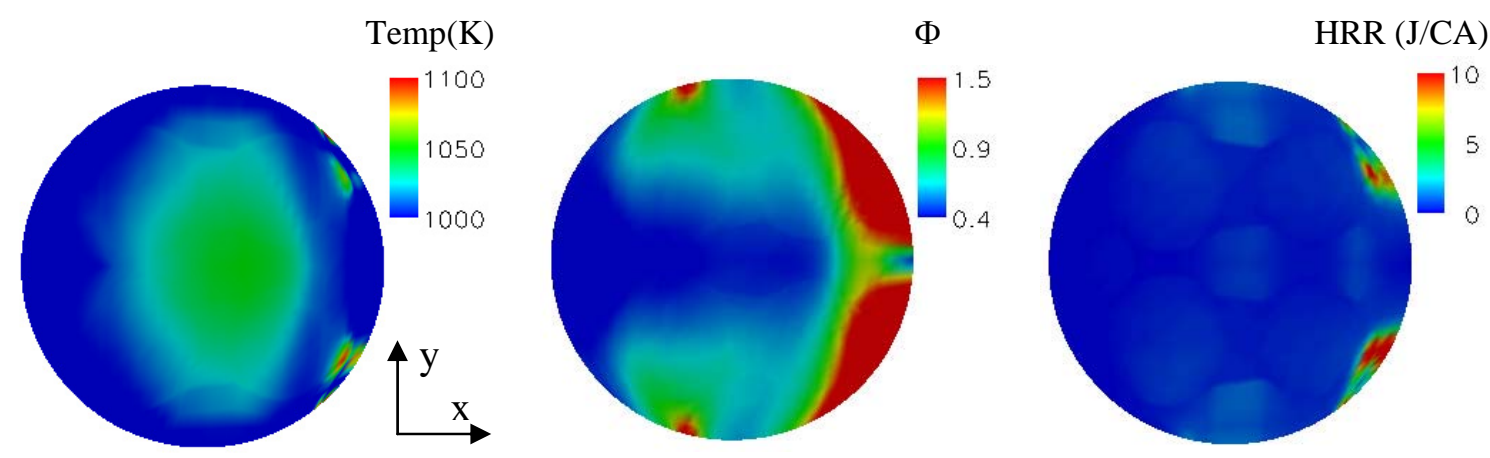

(b) SOI at $218^{\circ} \mathrm{ATDC}_{\text {overlap }}$

Fig. 15 The spatial temperature, equivalence ratio and heat release rate distributions at $350^{\circ} \mathrm{ATDC}_{\text {overlap }}$ for the cases with injections at $98^{\circ}$ and $218^{\circ}$ ATDC. 


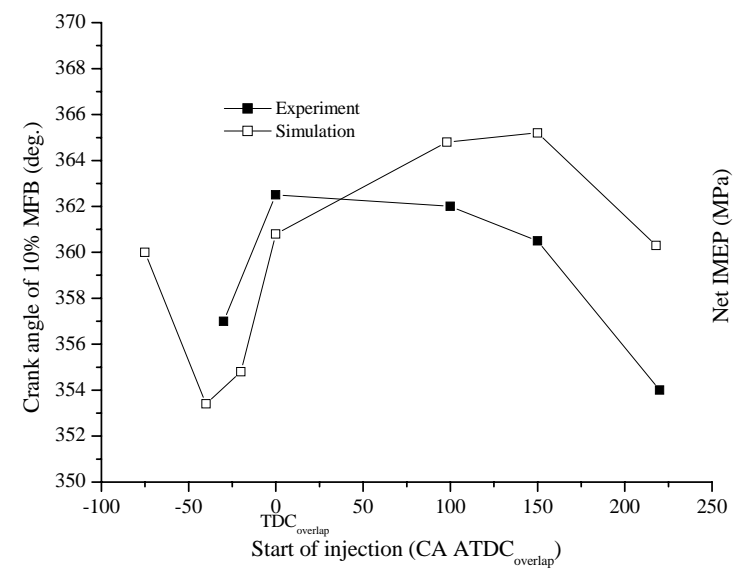

(a) $10 \% \mathrm{MFB}$

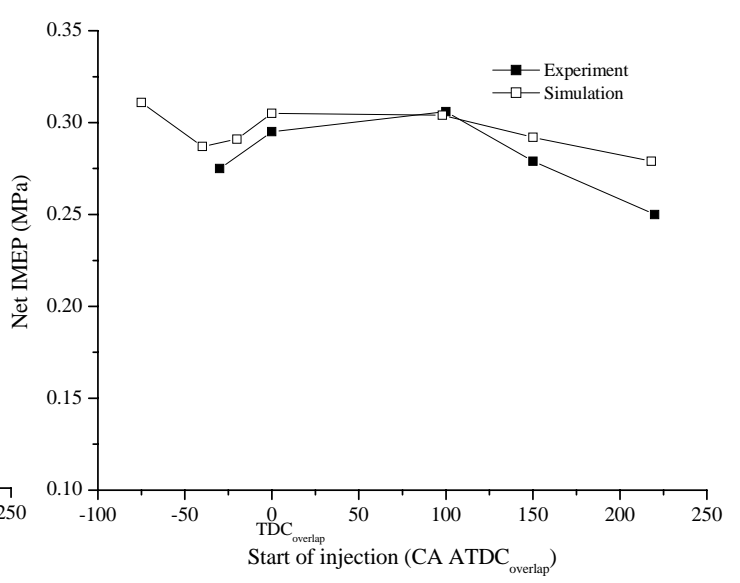

(b) Net IMEP

Fig. 16 Measured and predicted 10\% MFB and net IMEP.

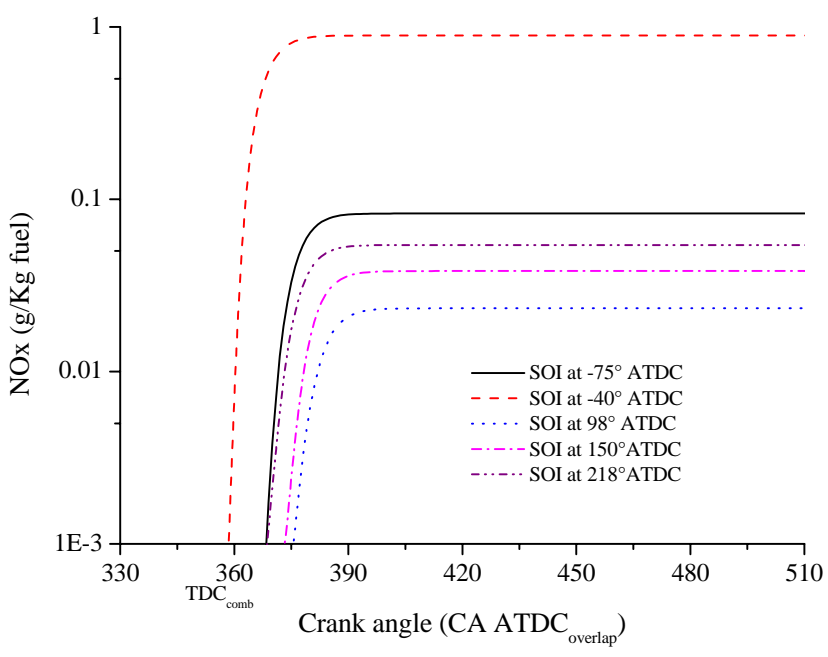

(a) $\mathrm{NOx}$

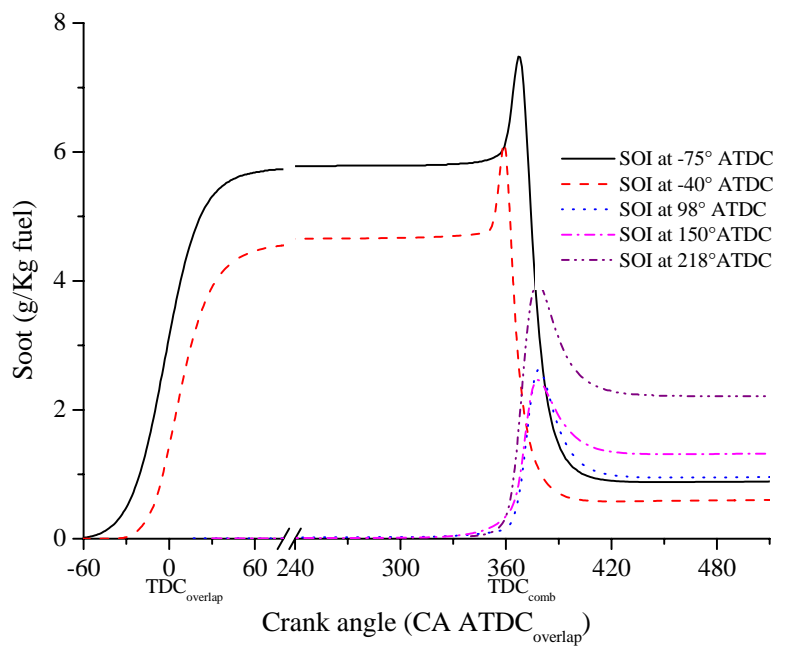

(b) Soot

Fig. 17 Predicted NOx and soot histories varying with injection timings. 


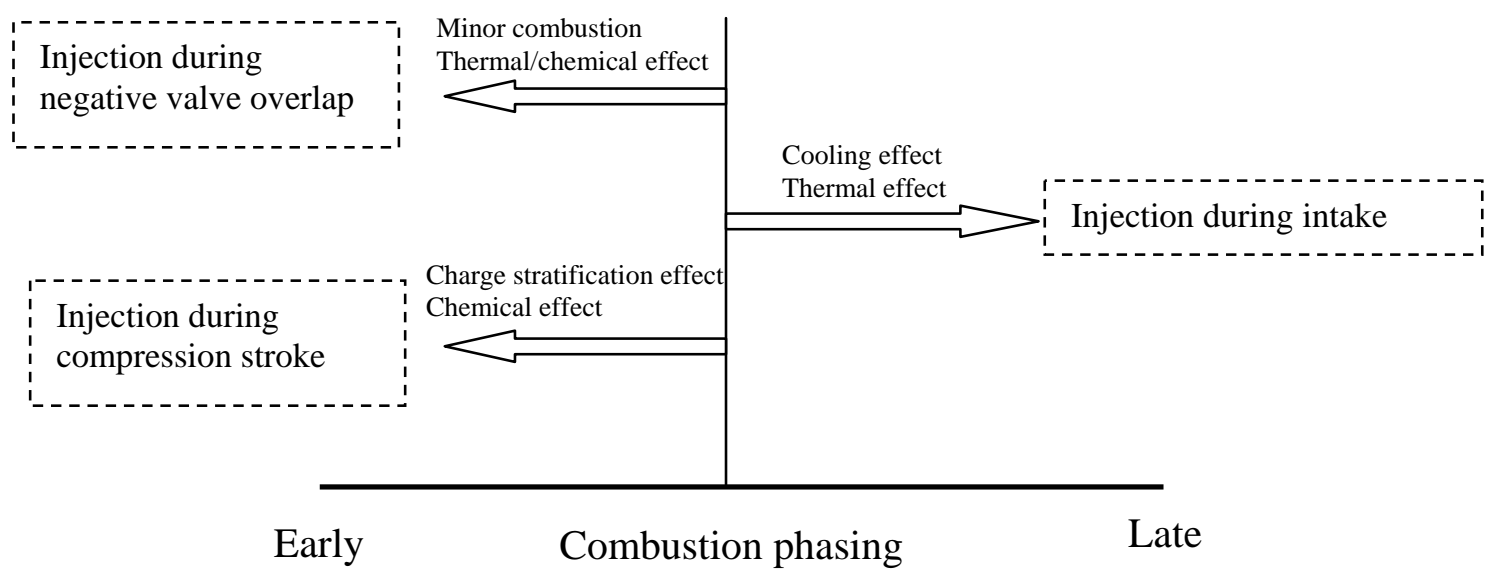

Fig. 18 Mechanism of combustion phasing control by injection timings.

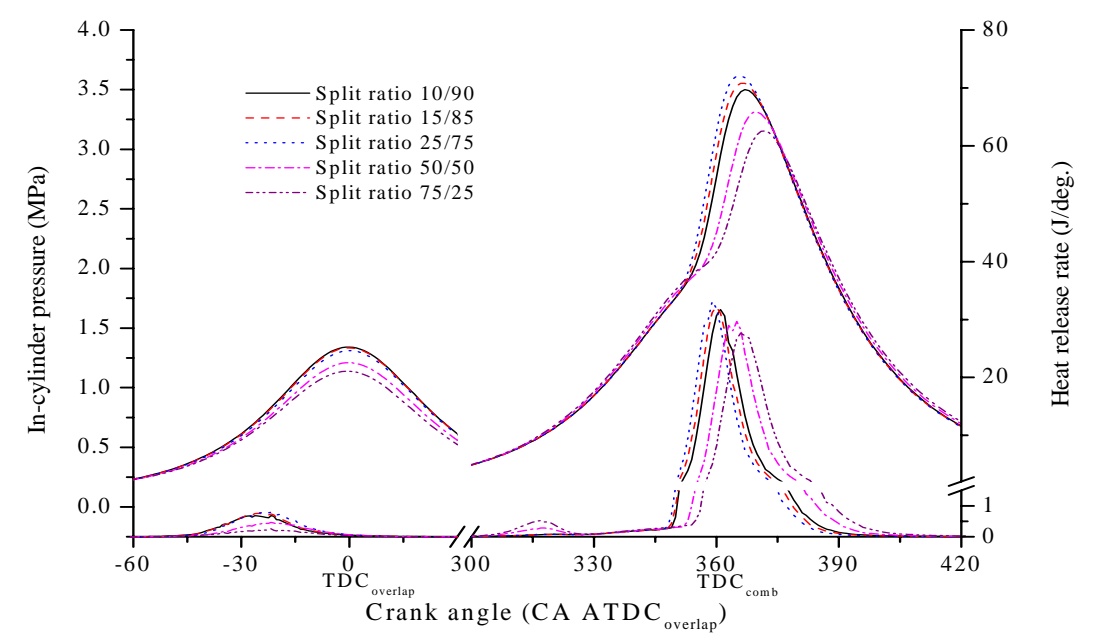

(a) Pressure and heat release rate traces

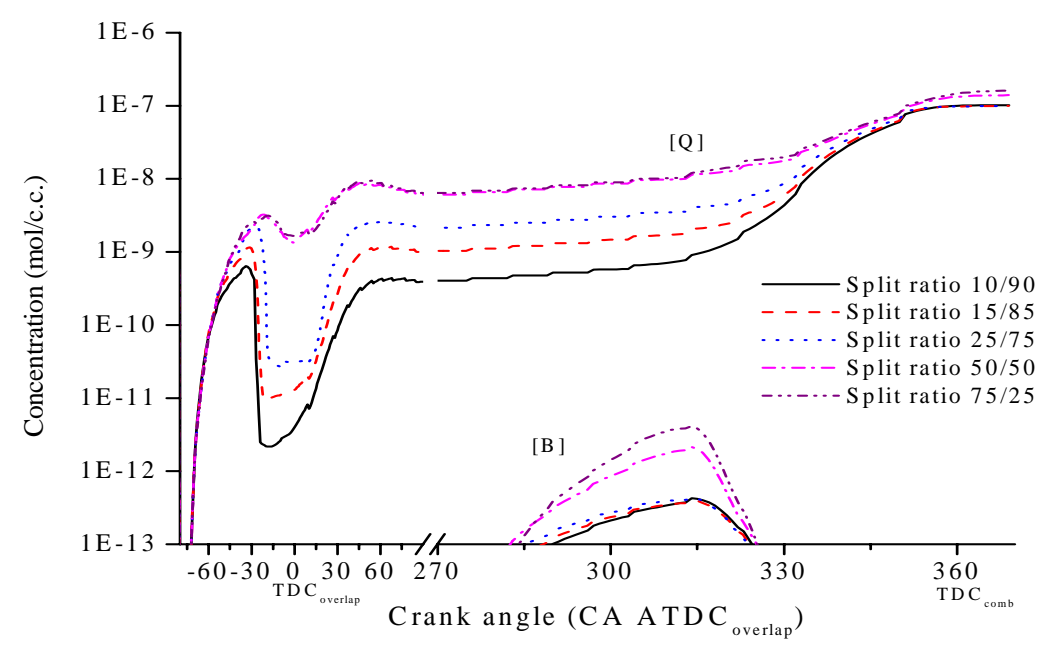

(b) Radical/intermediate species trace

Fig. 19 Pressure and heat release rate, radical species traces with variable split fueling. 

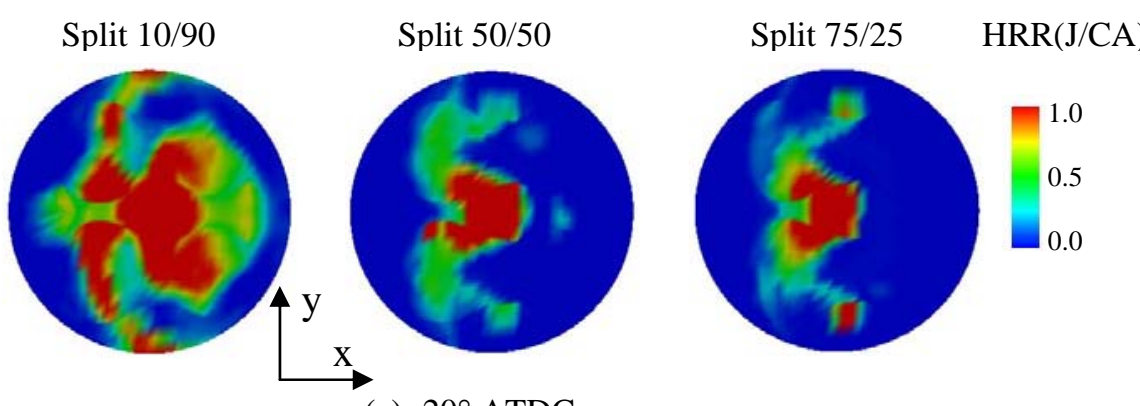

(a) $-20^{\circ}$ ATDC $_{\text {nverlan }}$
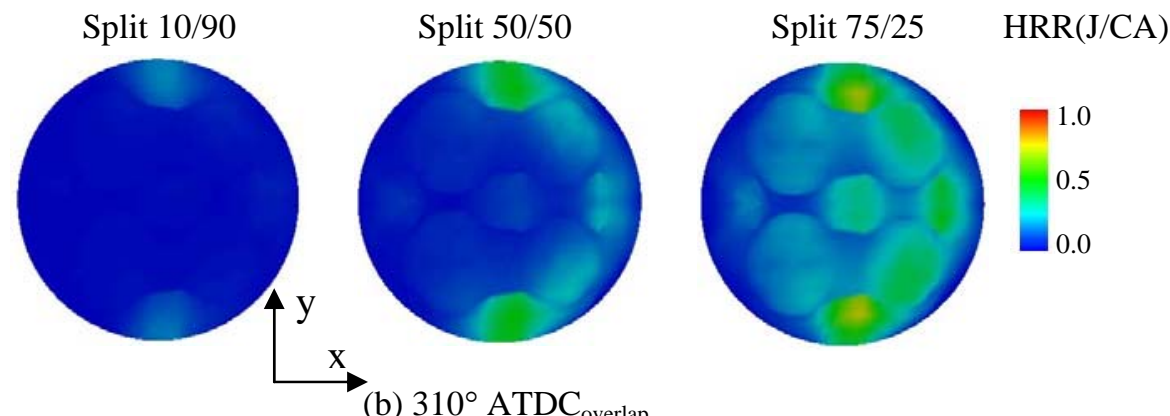

(b) $310^{\circ} \mathrm{ATDC}_{\text {overlap }}$
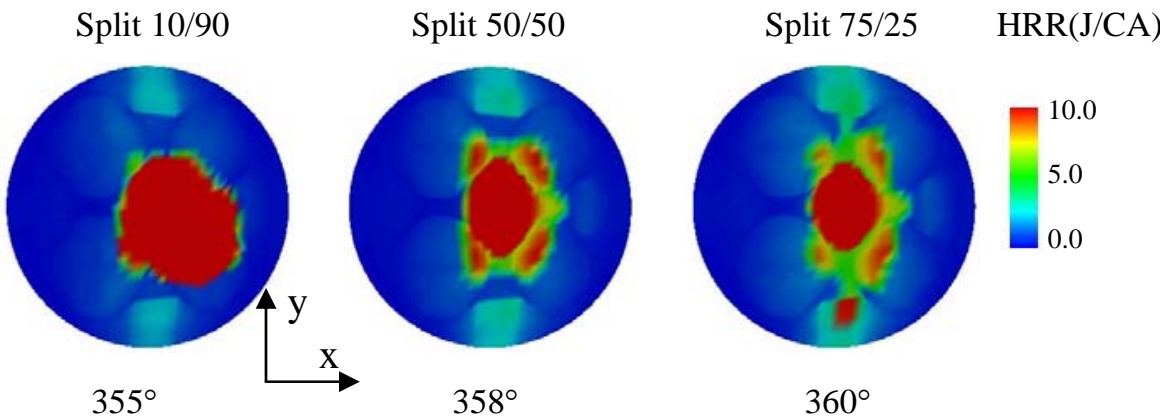

(c) $10 \% \mathrm{MFB}$

Fig. 20 Local heat release rate distribution of various split injections 


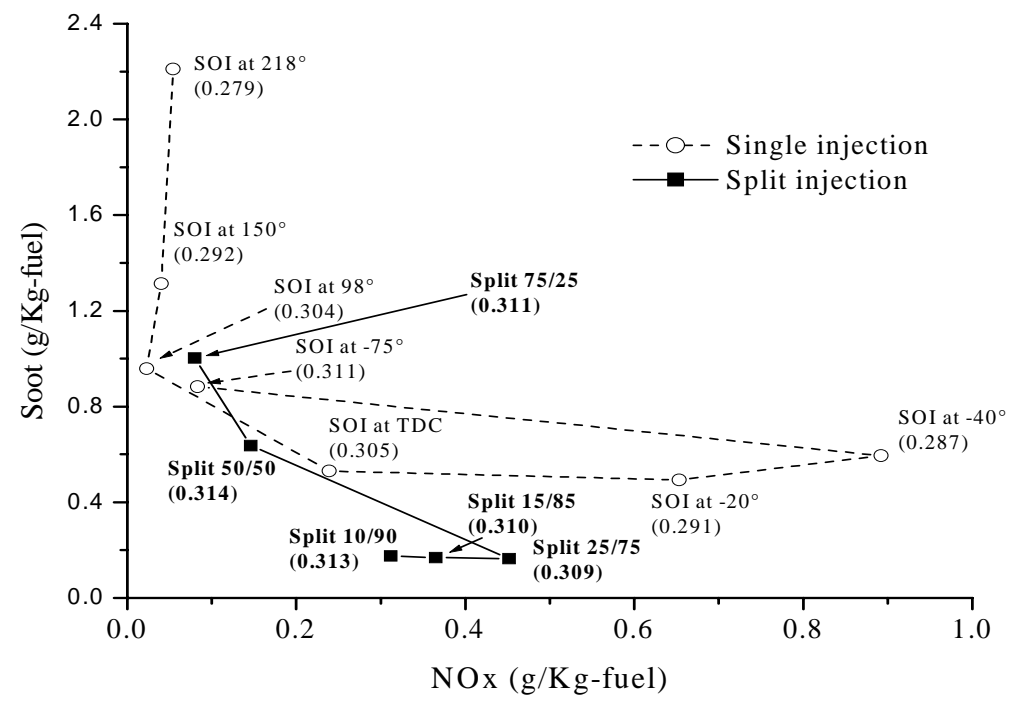

Fig. 21 Soot-NOx trade-off of single and split injections. Numbers in parentheses denote IMEP values.

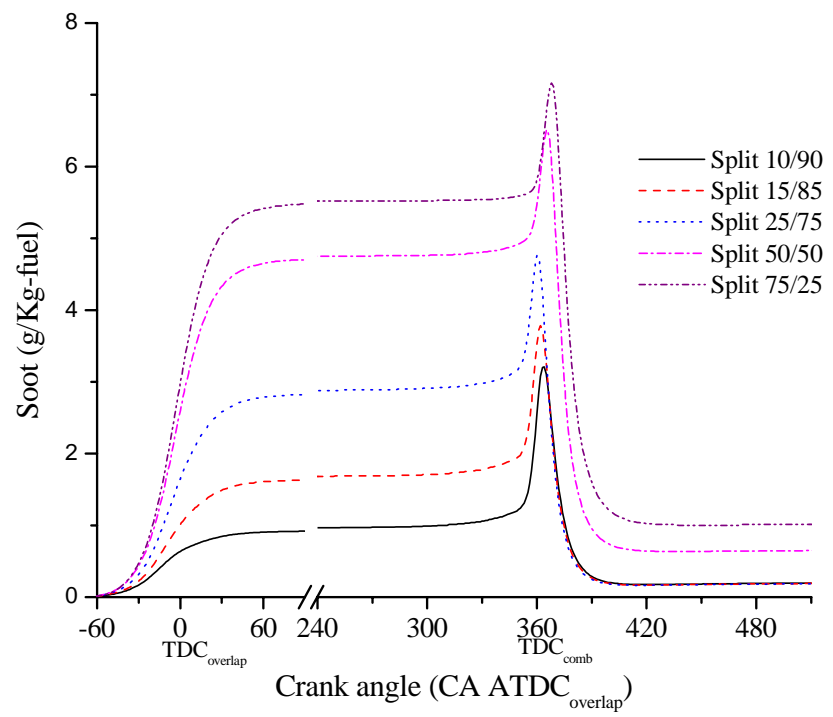

Fig. 22 Predicted soot histories of split injections 